\title{
EVALUATING THE RISK OF CHINESE HOUSING MARKETS: WHAT WE KNOW AND WHAT WE NEED TO KNOW
}

\author{
Jing $\mathrm{Wu}$ \\ Joseph Gyourko \\ Yongheng Deng \\ Working Paper 21346 \\ http://www.nber.org/papers/w21346 \\ NATIONAL BUREAU OF ECONOMIC RESEARCH \\ 1050 Massachusetts Avenue \\ Cambridge, MA 02138 \\ July 2015
}

We appreciate the comments of seminar participants at the Asian Bureau of Finance and Economic Research 3rd Annual Conference 2015, the 17th NBER-CCER Conference on China and the World Economy, the Federal Reserve Bank of New York and New York University. Gyourko thanks the Research Sponsor Program of the Zell/Lurie Real Estate Center at Wharton for financial support. Wu thanks the National Natural Science Foundation of China for financial support (No. 71003060 \& 71373006). We gratefully acknowledge Jingting Huang, Wei Guo, and Pu Wang for outstanding research assistance. The views expressed herein are those of the authors and do not necessarily reflect the views of the National Bureau of Economic Research.

NBER working papers are circulated for discussion and comment purposes. They have not been peerreviewed or been subject to the review by the NBER Board of Directors that accompanies official NBER publications.

(C) 2015 by Jing Wu, Joseph Gyourko, and Yongheng Deng. All rights reserved. Short sections of text, not to exceed two paragraphs, may be quoted without explicit permission provided that full credit, including (๑) notice, is given to the source. 
Evaluating the Risk of Chinese Housing Markets: What We Know and What We Need to

Know

Jing Wu, Joseph Gyourko, and Yongheng Deng

NBER Working Paper No. 21346

July 2015

JEL No. R11,R3,R31,R52

\section{$\underline{\text { ABSTRACT }}$}

Real estate is an important driver of the Chinese economy, which itself is vital for global growth. However, data limitations make it challenging to evaluate competing claims about the state of Chinese housing markets. This paper brings new data and analysis to the study of supply and demand conditions in nearly three dozen major cities. We first document the most accurate measures of land values, construction costs, and overall house prices. We then create and investigate a number of supply and demand metrics to see if price growth reasonably can be interpreted as reflecting local market fundamentals. Key results include the following:

(1) Real house price growth has been high, averaging 10\% per annum since 2004 . However, there is substantial heterogeneity across markets, ranging from 3\% (Jinan) to 20\% (Beijing). House price growth is driven by rising land values, not by construction costs. Real land values have risen by over15\% per annum on average. In Beijing, the increase has been by a remarkable $27.5 \%$ per year (or by 1,036\%) since 2004.

(2) There is variation about the strong positive trend in house price and land value growth. Land values fell by nearly one-third at the beginning of the global financial crisis, but more than fully recovered amidst the 2009-2010 Chinese stimulus. More recent growth has been much more modest, with some markets beginning to decline. Quantities of land sales by local governments to private residential developers have dropped sharply over the past two years. The most recent data show transactions volumes down by half or more. This should lead to a reduced supply of new housing units in coming years.

(3) Market-level analysis of short- and longer-run changes in supply-demand balances finds important variation across markets. In the major East region markets of Beijing, Hangzhou, Shanghai and Shenzhen which have experienced very high rates of real price growth, we estimate that the growth in households demanding housing units has outpaced new construction since the turn of the century. However, there are a dozen large markets, primarily in the interior of the country, in which new housing production has outpaced household growth by at least 30\% and another eight in which it did so by at least $10 \%$. Regression results show that a one standard deviation increase in local market housing inventory is associated with a 0.45 standard deviation lower rate of real house price growth the following year.

(4) There are no official data on residential vacancy rates in China, but some researchers have reported very high figures $(17 \%+)$. We develop a new series at the provincial level which yields a much lower vacancy rate on average, but it has been rising-from 5\% in 2009 to $7 \%$ in 2013.

(5) The risk of housing even in markets such as Beijing which show no evidence of oversupply, is best evidenced by price-to-rent ratios. They are well above 50 in the capital city. Poterba's (1984)user cost model suggests these levels can be justified only if owners have sufficiently high expectations of future capital gains. Even a modest one percentage point drop in expected appreciation (or increase in interest rates) would result in a drop in prices of about one-third, absent an offsetting increase in rents. 


\author{
Jing Wu \\ Tsinghua University \\ Heshanheng Building \\ Beijing 100084, China \\ ireswujing@tsinghua.edu.cn \\ Joseph Gyourko \\ University of Pennsylvania \\ The Wharton School of Business \\ 3620 Locust Walk \\ 1480 Steinberg-Dietrich Hall \\ Philadelphia, PA 19104-6302 \\ and NBER \\ gyourko@wharton.upenn.edu \\ Yongheng Deng \\ Institute of Real Estate Studies \\ National University of Singapore \\ Singaporeydeng@nus.edu.sg
}




\section{Introduction}

China's large share in global growth makes our understanding of the risks and opportunities in its housing markets of first order importance. Housing is not broken out separately in the Chinese national income accounts, but the real estate sector is quite large: it comprised 5.9\% of Chinese output in 2013, while the construction sector contributed another $6.9 \% .^{1}$ Unfortunately, it is extremely challenging to evaluate competing claims about conditions in Chinese housing markets, with data limitations being a key reason why. Private housing markets did not exist before the reforms of the late 1990s, so there is only a short time series over which variation in prices and quantities across markets can be examined (e.g., Wang (2011); Chen and Han (2014)). That is compounded by worries about the quality of official data on house prices. For example, there is no official constant quality price index reported based on large, representative samples of micro-level housing transactions.

The best data on house and land value appreciation comes from constant quality price series developed by academic researchers (Deng, Gyourko and Wu (2014); Wu, Deng and Liu (2014); Guo et al (2014); Fang et al (2015)). These series show much higher appreciation rates in aggregate, as well as greater short-term volatility, than official series reported by the government. Real constant-quality growth in overall house prices has averaged about $10 \%$ per annum on a compounded basis over the past decade. However, there is substantial heterogeneity across markets, ranging from a low of less than $3 \%$ per annum (Jinan) to a high of nearly $20 \%$ per annum (Beijing).

Overall house price growth has been driven by appreciation in local land markets, not by construction costs. The latter are flat to very modestly increasing in most markets. Real land

\footnotetext{
${ }^{1}$ Source: National Bureau of Statistics of China, "China Statistics Yearbook, 2014". The construction sector includes non-housing real estate and non-real estate activities such as infrastructure.
} 
prices have been appreciating at an average annual compound rate of over 15\% since 2004 across 35 large cities. Once again, there is substantial variation across cities, with real price growth escalating at $27.5 \%$ per annum in Beijing since 2004. Compound annual land prices growth has averaged just over 7\% in Dalian and Wuhan, but even that rate implies a doubling of real land prices since 2004.

We also track changes in quantities, not just prices. Series on the number of land parcels sold by local governments to private residential developers and on the amount of newly-built space sold each year show wide variation across years. The negative impact of the global financial crisis on transactions volumes in housing markets is clearly visible in these data, as is the positive impact of the Chinese financial stimulus in 2009-2010. More recent data from 2014 show a sharp decline in trading volumes. Land parcel sales at the end of the year were down $60 \%$ from levels transacted two years ago. This takes transaction volumes back to levels not seen since the global financial crisis. Whether changes in transactions volume lead changes in prices, as happened in the United States, remains to be seen. In addition, the reduced volume is likely to have a major impact on the health of local public finance in China, as many cities rely heavily on land sales to fund their activities and to service debt (e.g., Ambrose, Deng and Wu (2015); Fan, et. al. (2015); Tao (2015)).

Real house and land price appreciation have been quite high by U.S. standards, but it bears emphasizing how different are Chinese economic and housing market conditions. The high Chinese appreciation starts from a low price level in a country that still is urbanizing. Its overall economic growth also has been high over the past decade: $7 \%-10 \%$ per annum, which is about the level of real house price growth on average. Some markets such as Beijing have 
appreciated at far higher rates, but that just highlights the need to look at underlying supply and demand fundamentals to better gauge the sustainability of prices.

We look at a number of metrics in this regard in Section III. In aggregate, there have been big increases in the quantity of floor space completed in major markets over time. Among 35 large cities we track in the analyis reported below, the amount jumped about $50 \%$ after the 2009-2010 stimulus period and stayed at an elevated level. Substantial demand is needed to justify a supply increase that large. In fact, trend demand is strong in China, as its urban population has also grown about $50 \%$ between its 2000 and 2010 censuses.

Other measures are examined at the local market level. The first is annual supply of new space as a share of local market size. There is noteworthy heterogeneity across markets in this metric. The quantity of new supply is not increasing relative to market size in the strongest appreciating eastern markets such as Beijing and Shanghai. However, we do see rising supply in a variety of other major cities including Chengdu, Chongqing, Guangzhou, Tianjin and Xian. In 2014, private developers in Tianjin delivered new supply equal to $9 \%$ of the 2010 stock. Another measure examined is the amount of inventory held by private developers as a share of yearly sales volume in the market. There is no upward trend in this series for Beijing either, but that for Shanghai (and various other markets) is strongly positive.

Longer-run calculations of changes in the supply-demand balance also are reported. In aggregate, we find no overbuilding for the nation in the following sense: our estimate of the net increase in households living in urban areas exceeds net new housing units by about $10 \%$ between 2001-2012. While there is no evidence of aggregate overbuilding, there is substantial local heterogeneity, just as there was in price appreciation. Growth in the supply of dwelling space has far outpaced household growth by at least $30 \%$ in twelve major markets and did so by 
at least $10 \%$ in another eight. The dozen cities with the largest imbalances of new housing units supplied relative to growth in the number of households needing living space since 2001 include Chengdu, Guiyang, Harbin, Hohhot, Lanzhou, Nanchang, Qingdao, Shenyang, Wuhan, Yinchuan and Zhengzhou. However, the major eastern markets including Beijing, Hangzhou, Shanghai and Shenzhen have seen growth in households outpace net new construction since the turn of the century.

There are no official data on vacancy rates among owner-occupied housing units in China. Other researchers have reported very high rates in the high teens or above. We develope a new series at the provincial level using what we believe to be the highest quality data currently available. This series shows a much lower vacancy rate on average, but it has been rising in recent years-from 5\% in 2009 to 7\% in 2013.

The final two metrics examined are price-to-rent and price-to-income ratios. Housing units tend to trade at very large multiples of rent in China. Individual market ratios range from the low 20's to above 50 in Beijing. While high compared to U.S. data, there typically is no upward trend in these series. Poterba's (1984) user cost framework suggests these levels can justified if owners have sufficiently high expectations of future capital gains. The price appreciation needed to justify purchasing in Beijing is well within the range of recent experience in that market, but the same cannot be said for a number of other cities. Even in Beijing, this analysis should not be interpreted as indicating its housing market is not risky. In fact, these data imply high risk in markets where the user costs of owning are in the $2 \%-3 \%$ range (so that priceto-rent ratios are well over 33). Small drops in expectations of future appreciation (or commensurate rises in interest rates) imply a large negative adjustment in price levels, absent offsetting increases in rents. 
Price-to-income data highlight another risk for housing markets that look solid in terms of supply-demand fundamentals. These ratios also are very high by U.S. standards ( 8 is typical and Beijing's ratio always is well over 10), but they are consistent with standard Chinese underwriting, which presumes continued high income growth in urban areas. Of course, that is the embedded risk. If for any reason that growth does not materialize, housing will be unaffordable in most places, and in the most expensive east region markets in particular.

Section IV concludes our analysis by empirically investigating whether changes in some of these market fundamentals can account for variation in house prices over time within a market. They can, as we document that the magnitude of the inventory overhang in a market at the end of this year is an economically and statistically significant predictor of price change the next year. A one standard deviation higher normalized housing inventory in a market is associated with a 0.45 standard deviation lower rate of house price growth the following year (ceteris paribus). Thus, oversupplied local markets are likely to suffer price declines (or lower growth) than markets with better underlying fundamentals.

The plan of the paper is as follows. The next section discusses and analyzes the two primary official series on house prices and contrasts them with a land price measure we have introduced and an unofficial constant quality house price series in development. Section III then investigates a number of other metrics that can be used to gauge housing market conditions. Section IV examines whether these measures can explain the variation in price changes across markets. There is a brief conclusion.

\section{II. $\quad$ Prices and Quantities in Chinese Housing Markets $\underline{\text { Official House Price Series }}$}


The National Bureau of Statistics of China (NBSC) reports two series on house prices. One called "Price Indices for Real Estate in 35/70 Large and Medium-sized Cities" tracks prices measured at the housing complex level within city. An average transaction price is calculated for each sampled housing complex at a monthly frequency, and then compared with that for the same (or comparable) complex in the preceding month. The NBSC then calculates a monthly house price growth rate at the city level as the weighted average of the growth rates of all sampled complexes in the corresponding month.

This series originally covered 35 major markets and expanded to 70 in July of 2005. Unfortunately, it is not reported consistently over time because the NBSC adjusted its data and/or computational strategies at the beginning of 2011 in ways not fully detailed for the public. While results are not strictly comparable before and after that time, splicing together the June 2005-December 2010 and January 2011-December 2014 periods finds real aggregate house price growth is reported to be only $16.7 \%$ at the national level, for an implied compound annual growth rate of $1.6 \%$. Many observers do not find this pattern consistent with the reality of Chinese housing markets on average, and we agree. ${ }^{2}$

A second government-provided series is the "Average Selling Price of Newly-Built Residential Buildings” (“Average Price Indices”, hereafter). Since the mid-1990s, real estate developers in China are required to report a variety of business indicators to the government statistics agency, including the total volume (in floor area) of newly-built housing units sold within each sampling period and the aggregate sales price of these units. Dividing the total price paid by total floor area of the transacted units, weighted average house prices per square meter

\footnotetext{
${ }^{2}$ For example, reports from the Financial Times ("Fears of China Property Bubble Grow", Mar 10, 2010), China Daily ("Doubts over Increase in Property Price", Feb 27, 2010) and Wall Street Journal ("China Underestimated House Price Growth in Beijing, Shanghai”, Jan 28, 2013) show their concerns on the low growth rates suggested by this index.
} 
are calculated and reported at the city, province, and national level, respectively. To be more precise, if ten units with 100 square meters each were sold in a market for an aggregate amount of one million yuan, the reported price would be 1,000 yuan per square meter.

Reported house price growth is much higher in this series and there is substantial variation across markets. Table 1 lists aggregate and implied real compound appreciation rates between 2004 and 2014 from this series for 35 major markets that will be the focus of much of the analysis in this paper. The map in Figure 1 shows that this set includes many non-Tier 1 cities that are spread throughout China's regions. The value of newly-built housing in these markets equals nearly one-half of the value of all new homes in China. The interquartile range of aggregate real price growth across these 35 cities runs from $95.8 \%$ to $162.2 \%$. Thus, threequarters of these major markets are estimated to have experienced close to or substantially more than a doubling of real prices since 2004. Implied per annum real appreciation rates over the past decade range from a low of $3.9 \%$ (Yinchuan) to a high of $14.3 \%$ (Xiamen) in these data.

\section{$\underline{\text { Construction Costs }}$}

The price of newly built housing reflects the sum of the price of land and improvements (i.e., the physical housing units), in addition to the developer's profit. To gauge whether construction costs have been escalating sharply in China, we constructed a basket of representative construction cost items including building materials prices, construction worker wages, and expenses for construction machinery. Those costs are from the NBSC based on surveys conducted by local statistical agents. The average increase in real construction costs across our 35 markets from 2004-2013 is only $8.1 \%$ in aggregate, or $0.9 \%$ per annum on a compounded basis. The largest increase is $17 \%$ in Xian and real costs actually fell by $1 \%$ over 
the decade in Beijing. Thus, construction cost increases cannot account for the large increases in real house prices depicted in the Average Price Indices series.

\section{$\underline{\text { Land Price Data }}$}

Modest increases in real construction costs imply that house price growth must have been driven primarily by land price growth in China. The only currently available official data on land prices in China come from the "China Urban Land Price Dynamic Monitor" system reported by the Ministry of Land and Resource of China. It tracks parcel values in over 100 major cities. Its land price indexes are appraisal-based, and are not derived from actual market transactions. In each city, representative land parcels are selected as "monitoring points" by technicians employed by local land authorities. For example, there are 257 such land parcels in Beijing. Of that total, 98 are for residential usage. Local land appraisals are conducted each quarter for every parcel. City, regional, and national-level average land prices and price indexes are then computed. This land price series tends to be quite smooth over time, and does not show markedly high appreciation in land values on average. For example, real growth of the aggregate residential-usage land price index at the national level between 2004 and 2014 was 54.2\%, for a 4.4\% per annum implied compound growth rate.

This stands in sharp contrast to another land price index that we developed in previous research (Deng, Gyourko and Wu, 2014). This “Chinese Residential Land Price Index” (CRLPI) is a constant-quality, residential land price index based on sales of long-term leasehold estates to private developers in the same set of 35 large cities listed in Table 1. China is one of the only countries in the world for which it is possible to frequently observe transactions involving vacant residential land. This is because the Chinese government retains ownership of all urban land. 
Since 1988, private developers have been able to purchase use rights from the government for up to 70 years on residential properties. Developers make a single, upfront payment to the relevant local public entity. Our series treats that payment as the transactions price of the land parcel, but it clearly is for a lengthy (but finite-lived) leasehold estate.

This series begins in the first quarter of 2004 and presently runs through the fourth quarter of 2014. Table 2 reports the number of cities covered each year, along with the number of land parcels sold. This land price index adjusts average transactions prices for various differences in site quality via a hedonic model that is estimated at the city level for a dozen large markets at an annual frequency, at the regional level on a semi-annual basis, and the 35 city aggregate level on a quarterly basis. Each land parcel is equally weighted. ${ }^{3}$

Figure 2's plot of this aggregate series depicts extremely high real land price growth across these markets over the past 44 quarters. Real prices have appreciated by $357 \%$ since 2004(1), for an implied real average annual compounded appreciation rate of $15.2 \%$ (3.6\% on a quarterly basis; see Table 3). There is variation about this very strong decade-long trend, with real land values dropping by about one-third between 2007(3)-2009(1) as the global financial crisis occurred. That this was followed by a more than doubling of real prices during the massive Chinese stimulus period in 2009 provides an indication of how important government policy likely is for this sector. Real land price growth then was flat during most of 2011 and 2012 before escalating again in 2013. In 2014(3), there is a decline of 6.8\%, which takes the series back to its 2013(3) level, but the index rebounded by 10.7\% in the last quarter of 2014.

This aggregate series masks sometimes substantial heterogeneity at more local levels. This is not so evident in the regional data plotted in Figure 3. There is a strong common trend across land markets in all three regions, although the most recent data show a downturn in the

\footnotetext{
${ }^{3}$ Deng, Gyourko and $\mathrm{Wu}(2014)$ describe the underlying data sources and index construction in detail.
} 
West and Middle regions, but not the East. Real, constant quality land price growth ranges from $231 \%$ in the West region to $326 \%$ in the Middle region (see Table 4).

More variation is visible across the 12 large cities for which annual indexes are reported in Figure 4. The first two columns of Table 5 show that real land price growth has been strong in each of these cities between 2004-2014, with only three being below $10 \%$ on an average annual compound basis (7.2\% in Dalian; $7.3 \%$ in Wuhan; $8.6 \%$ in Xian). Real price growth in Beijing has averaged an astounding $27.5 \%$ per year since 2004 , for an aggregate increase of over 1,000 percent. No other city approaches this magnitude, but four other markets have real average annual compound appreciation rates over 15\% (Shanghai, Chongqing, Tianjin, and Guangzhou). The remaining four experienced still strong price growth of between 10\%-15\% per year (Hangzhou, Changsha, Nanjing and Chengdu). ${ }^{4}$

\section{$\underline{\text { Discussion }}$}

The middle set of columns in Table 5 incorporate the government's Average Price Indices data. Land price appreciation is greater than reported house price growth in most, but not all, of these major markets. In Beijing, Changsha, Chongqing, Nanjing, Tianjin and Shanghai, aggregate land price growth is more than 100 percentage points higher than the government's Average Price Indices.

Reconciling our high land price appreciation rates with the government's house price appreciation estimates requires that land constitute a relatively small share of overall house value. We doubt that is reasonable, especially in markets such as Beijing. A simple comparison would start with the following identity, which states that overall house price is the weighted sum of the

\footnotetext{
${ }^{4}$ The CRLPI for Beijing reports real land price appreciation that is 900 percentage points higher than the government's appraisal-based series. No other gap is as wide, but the differences in aggregate appreciation typically are wide - 300+ percentage points in other cities such as Chengdu, Hangzhou and Shanghai.
} 
value of the land and the building improvements, with developers earning a standard profit on that sum. More specifically,

$\left(P_{l}+P_{b}\right) * \operatorname{Dev}_{p}=H P$

where $P_{l}$ and $P_{b}$ are the prices of land and building improvements, respectively; $D e v_{p}$ is the developer's profit margin, and $H P$ is the overall house price. If we presume that only the price of land and building improvements changes, the growth rate of house price $(\mathrm{gHP})$ can be calculated as equation (2):

$\left(s_{l}{ }^{\mathrm{g}} P_{l}\right)+\left(s_{b}{ }_{\mathrm{g}} P_{b}\right)=\mathrm{g} H P$

where $\mathrm{g} P_{l}$ and $\mathrm{g} P_{b}$ are the price growth rates of land and building improvements, respective; $s_{l}$ and $s_{b}$ are the share of land and building improvements in overall house value, respectively.

Equation (2) allows us to experiment with different land and building shares to see whether our land price series is consistent with the government's house price series. If land has a $50 \%$ share in overall house value in Beijing, equation (2) implies either that our land price growth measure is biased upward or the government's house price growth is biased downward. Using the $1036 \%$ real land price growth from Table 5 and a $1 \%$ decrease in construction costs yields the following:

$(0.5 * 1036 \%)+(0.5 *-1 \%)=518 \%>>226 \%$

The implied house price growth is $518 \%$, which is far greater than the $226 \%$ reported by the government's Average Price of Newly-Built Housing series. In contrast, if one thought land share in Beijing was only $20 \%$, the equation becomes $207 \%$, which would be close to the government's house price series.

One noteworthy effort to improve the quality of house price measurement is $\mathrm{Wu}$, Deng and Liu (2014). They estimate a hedonic model to create a constant-quality house price index 
based directly on micro transactions data of all newly-built housing units in the 35 major city sample we are using. While Wu, Deng and Liu's (2014) data stopped in 2010, Table 6 lists the aggregate and implied real compound annual appreciation rates based on constant-quality prices between 2006 and 2014. In general, it suggests a higher appreciation rate than the Average Price Index reports for most, but not all, 35 markets. For example, the series for Beijing finds total real house price growth of about 385\% between 2006(1)-2014(4), which implies a real average compound appreciation rate of $19.8 \%$ ( $4.6 \%$ on a quarterly basis). This is about 8 percentage points above the rate measured in the Average Price Indices. Using this higher figure for $\mathrm{g} H P$, a land share of about $72 \%$ results in overall annual house price growth of $19.8 \%$ based on equation (2). While not available to the public, we work below with updated constant quality house price data from Wu, Deng and Liu (2014). We view its index construction as superior because it is directly based on micro-level transactions data, with an additional effort made to adjust for changing trait quality over time. Those data show very high real house price appreciation rates, with an average of about $10 \%$ per annum for 35 major markets over the past decade (Table 6). There is wide variation in growth across markets, ranging from $2.8 \%$ (Jinan, column 2, Table 6) to $19.8 \%$ (Beijing, column 2, Table 6). ${ }^{5}$

\section{Quantities: Transactions Volumes}

Short time series on land parcel sales and the square meters of newly-built housing sold are available. The land parcel sales data are from the 35 markets tracked in the CRLPI and are plotted in Figure 5. There is considerable volatility in these data. It shows a doubling in the quantity of land parcel purchases from around 200 to 400 per quarter in the cities covered by the

\footnotetext{
${ }^{5}$ Very recent work by Fang, et. al. (2015) based on mortgage data from a large lender uses a hybrid approach that builds price indexes from 2003-2013 based on sequential sales of new homes within the same housing development. They also find high average real price appreciation and substantial variation across markets.
} 
CRLPI from the beginning of 2005 through the end of 2006. Transactions volume fluctuated around that higher level until the global financial crisis hit China in 2008. By the beginning of 2009, the number of parcels sold had fallen back just below 200. The stimulus period in 20092010 then saw a dramatic rebound, with sales escalating well above 500 in the fourth quarter of 2009. There are strong seasonal effects in these sales data, and the series fluctuates fairly widely between 350 and 550 per quarter until the third quarter of 2012, after which we see a sharp spike to 700 , before volumes fall back down to the 500 level. There have been fewer than 400 purchases in each quarter of 2014. In the last quarter of 2014, there were only 277 sales, $56 \%$ of the sales volume from a year earlier in 2013(4) and only 40\% of the number sold two years earlier in 2012(4).

Figure 6 plots the year-over-year growth in total square meters of newly-built housing units that are sold, as provided by National Bureau of Statistics of China. This series starts in 2007(1), with the latest data available from the last quarter of 2014. It also exhibits a sharp spike in sales volume leading up to the financial crisis, followed by a dramatic decline. The impact of the beginning of the stimulus period in 2009 is clearly visible, as is the mean reversion after that. The sharp rise in transactions in 2012 is evident. Growth in transactions volumes of newly-built units has been declining since the beginning of 2013, and all four quarters in 2014 show absolute declines in year-over-year growth.

The short-term volatility in Chinese housing market transactions quantities is markedly different from the U.S. data, which is depicted in Figure 7. Transactions volumes do fluctuate widely over the housing cycle in America, but they do so more smoothly over quarterly or even annual periods. Some of the difference may be due to the Chinese government intervening in the housing and mortgage markets much more frequently and forcefully than does the U.S. 
government. That is an area urgently in need of more research. ${ }^{6}$ This figure also shows that change in trading volumes led price changes by about 12-18 months, both at the peak and trough of the cycle. Only time will tell if this pattern holds in the Chinese data, too, but if it does, the recent declines in trading volumes in land parcels and square footage of new unit sales are foreboding.

\section{III. $\quad$ Thinking About Risk: Can Chinese Price Growth Possibly Be Explained by Fundamentals?}

Prices reflect the intersection of supply and demand, so one cannot tell all that much simply by looking at their levels or rates of growth. Moreover, the very high growth rates of Chinese house prices need to be kept in perspective. For example, the 1995-2005 U.S. housing boom saw real prices increase by about $50 \%$ at the national level, with so-called 'bubble markets' such as Las Vegas, Phoenix and Miami escalating by from 100\% in Las Vegas to 130\% in Miami over the same time span. Those certainly are far lower than what we believe to be credible data shows for many major Chinese housing markets. However, it is critical to recognize that prices started from different levels at the beginning of each country's boom, with the appreciation in China coming off a very low base. Differences in economic growth across the two countries also are large. From 2004-2013, Chinese GDP grew in real terms at an average compound real rate of $10.2 \%$ or by over $160 \%$ in aggregate. That is roughly four times the $42 \%$ real aggregate growth during the U.S. housing boom years from 1995-2005. And, as we show just below, real income growth also has been much higher in China, particularly in its urban markets.

\footnotetext{
${ }^{6}$ See Du and Zhang (2015), Cao, Huang and Lai (2015) for example for some recent research on this topic.
} 
While it is challenging to execute a convincing econometric analysis on such a short time series, there are a number of other metrics by which one can judge the risk that Chinese housing markets are substantially overpriced. Developing those measures and interpreting them is the purpose of this section. We start with what we consider the most intuitive: measuring whether growth in the quantity of housing supplied has outpaced demand as reflected in the number of households needing a place.

\section{Supply and Demand: Units and Households}

It is well known that demand-side fundamentals tend to be quite strong in most Chinese housing markets. Even without rapid national population growth, an on-going, massive rural-tourban migration underpins strong demand for housing units in Chinese cities. According to the two latest National Population Censuses by NBSC, the urban population in China increased from 458.8 million (36.9\% of total population) in 2000 to 670.0 million (50.3\% of total population) in 2010 , for an average compound growth rate of about $3.9 \%$. Urban household income also has grown substantially as the Chinese economy has prospered over the past couple of decades. The average annual compound real growth rate of per capita disposable income for urban households reached $9.2 \%$ between 2004 and 2013 according to NBSC. The importance of these demand factors are also highlighted in recent research (Chen, Guo and Wu (2011); Fang, et. al. (2015); Garriga, Wang and Tang (2014); Huang, Leung and Qu (2015); Wang and Zhang (2014)).

Less is known about the supply side of the housing market, but some research suggests that high and rising prices are due at least in part to some type of natural constraint or restrictive behavior by local governments (e.g., Wang, Chan and Xu (2012); Wu, Feng and Li (2014)). 
Figure 8 begins our documentation of supply side conditions with its plot of the ratio of new housing supply as a share of the 2010 stock in the 12 major markets for which land price growth was reported above. ${ }^{7}$ The first panel shows that residential space is not rising as a share of overall market size in Beijing and Shanghai, but is in Tianjin and Chongqing. In 2014 alone, developers in Tianjin delivered new space equal to over $9 \%$ of the 2010 stock; in Chongqing, the analogous figure is nearly $6 \%{ }^{8}$ The other panels of Figure 8 document rising trends in other markets such as Xian, Chengdu, and Guangzhou.

Figure 9 gauges supply in another way for these same markets, this time with unsold inventory held by developers as a share of yearly sales volume in the same market. ${ }^{9}$ A value of 0.5 implies that unsold inventories equal six months of average sales volumes in the same market. Consider the series for Beijing in the first panel. There are sharp spikes in unsold inventories relative to sales volume in 2008 during the global financial crisis and in 2010 and 2011 amidst the national stimulus program. Inventory relative to transactions volume was low in 2012 and 2013, but increased in 2014. This ratio has been trending up in Shanghai since 2007. Inventories in Shanghai now equal about 24 months of sales volumes. Other markets such as Dalian, Changsha, and Xian recently have seen multiple years of similarly high levels of unsold inventory relative to overall market sales volume.

Table 7 provides another perspective that confirms inventory levels have been rising not just absolutely, but relative to the scale of activity in the market. It reports data on a balanced

\footnotetext{
${ }^{7}$ In this measure, the numerator is the annual volume (in floor area) of newly-built housing completion as reported by local statistics agency. The denominator, the housing stock in 2010, is calculated based on the per capita living space of urban households and urban population in 2010, both reported in the National Population Census. Ratios for all 35 major markets discussed above are available upon request. These dozen cities capture most of the local variation across the 35 cities.

${ }^{8}$ To help put these numbers in perspective, it may be useful to know that housing permits in Phoenix, one of the U.S. 'bubble markets', did not quite reach $6 \%$ at the height of its boom.

${ }^{9}$ The numerator is the inventory (in floor area) of newly-built housing units held by developers at the end of the year. The denominator is the transaction volume (in floor area) of newly-built housing units sold during this year. Both are reported by local housing authorities.
} 
panel of 119 property development firms listed on the Shanghai and Shenzhen stock exchanges. The first column reports average turnover rate as reflected by the mean sales-to-asset ratio for these firms. Under Chinese accounting rules, a housing developer's inventory includes all land parcels purchased and housing units under construction, including those already presold to households. We adjust that number to exclude all advance payments from presold units and report it in the second column. Normalized inventory, which standardizes by the level of assets, is reported in the final column. Absolute and relative inventory levels clearly have risen over time, with a higher plateau roughly double that experienced in 2004 being reached following the stimulus period. Those high inventory levels have been maintained over time.

Figure 10 helps us understand the rapid increase of housing inventory held by developers during recent years. Floor space in aggregate housing starts in the 35 major cities fluctuated between 200 and 300 million square meters before 2009, but then jumped by about $50 \%$ to over 450 million square meters in 2010 following the stimulus. It has remained around this level since then. One needs more than modest growth in demand to keep pace with a surge in supply that large. For many cities, that growth did materialize, but not in others. In those places, inventory started to increase when the huge volume of housing starts were converted to effective supply in the market.

We also investigated longer-run changes in quantities in our 35 major markets. More specifically, the increase in the number of households is compared to the number of units supplied during the same interval. It is surprisingly difficult to estimate these quantities for Chinese cities for a number of reasons (e.g., urban boundaries change, the housing units of some local households are torn down so they need a unit even though they did not migrate into the city, etc.). They require a number of assumptions to be made. Appendix 1 describes them and 
the entire estimation process in detail. While we obviously made what we consider the best choices, readers are encouraged to review that section carefully.

Table 8 reports our results. The top row of the table is for the entire nation. In aggregate, during the decade between 2001 and 2010 growth in the number of households needed a housing unit exceeded the increase in the supply of units by nearly $14 \%$. However, there was an oversupply of units relative to households of about 10\% in 2011 and 2012, which resulted in supply falling short of our estimate of demand by about 10\% over the full 2001-2012 period. Once again, that aggregate average masks important heterogeneity across markets. This is highlighted by contrasting the cases of Beijing and Chongqing, the two cities with the $1^{\text {st }}$ and $2^{\text {nd }}$ highest land price appreciation rates and the $1^{\text {st }}$ and $3^{\text {rd }}$ highest house price growth rates. Our calculations suggest that the number of new units supplied in the capital city has been sufficient to satisfy only $80 \%$ of our estimate of the growth in households living in Beijing since 2000. This stands in stark contrast to the situation in Chongqing. In that city, additions to net new supply appear to have been almost $90 \%$ more than the increase in households. Other markets in which we estimate that net new supply has exceeded the net increase in households by at least 30 percent include Chengdu, Guiyang, Harbin, Hohhot, Lanzhou, Nanchang, Qingdao, Shenyang, Wuhan, Yinchuan, and Zhengzhou. Another eight saw net new supply exceed net new demand by from 10\%-30\% (Changsha, Fuzhou, Kunming, Nanjing, Nanning, Shijiazhuang Taiyuan, and Tianjin). That means 15 markets did not see supply outpace demand this century (by more than $10 \%$, a magnitude that we consider well within the range of estimation error). This group includes many of the largest markets in the East region of China such as Beijing, Guangzhou, Shanghai, and Shenzhen, as well as other coastal markets such as Hangzhou and Xiamen. 


\section{$\underline{\text { Residential Vacancy }}$}

If quantity supplied really has outpaced the growth in the quantity of units demanded in a market, then the vacancy rate should have increased. Measurement of residential vacancy is of great interest in China, but data limitations once again make it very hard to document convincingly. There has been no official housing survey that could provide a reliable estimate since the first National Urban Housing Census in $1985 .{ }^{10}$ This has led some researchers to conduct independent surveys on urban households. Perhaps the most well-known is the China Household Finance Survey (CHFS) at Southwestern University of Finance and Economics (Gan, 2012). For their latest report in 2013 , they surveyed 28,000 households around the country, with each household sampled providing the total number of dwelling units it owned, as well as the number of units leased out. Presuming that a household occupies only one unit at a time, the number of vacant units owned by the household can be calculated. Aggregating across households, they reported a very high nationwide vacancy rate of $22.4 \%$ in $2013 .{ }^{11}$

Other researchers have imputed a vacancy rate indirectly from macro-level statistics. For example, researchers from China International Capital Corporation (CICC), a leading investment bank, started with the data from the National Population Census in $2010 .{ }^{12}$ This source reports the breakdown of urban households by the number of bedrooms they were: 1) occupying; or 2) owning and leaving vacant. After making some assumptions on the average number of

\footnotetext{
${ }^{10}$ Sporadic region-level surveys exist such as the housing census conducted in 2007 by the Beijing local government, but in most cases official statistics were not published and no micro data were released.

${ }^{11}$ The results are reported in "The Vacancy Rate of Urban Housing and Trend in the Housing Market" (in Chinese) released in June 2014 on the official website of CHFS (www.chfs.swufe.edu.cn).

${ }^{12}$ The results are reported in "Are Vacancy Rates too High in China" (in Chinese) released on June $19^{\text {th }}, 2014$ by CICC (www.cicc.com).
} 
bedrooms per unit, the CICC imputed a housing unit-level vacancy rate of $18.3 \%$ for the nation in $2010 .{ }^{13}$ A recent update at the end of 2013 indicates a slightly lower level of $17.7 \%$.

We would expect vacancy rates that high to have exerted a material dampening effect on house price appreciation that one does not see in the data in most markets. Hence, we make an independent measurement using existing data (not a new survey) that allows us to compute vacancy rates at the provincial level. More specifically, we use micro data from the Urban Household Survey $(U H S)$, an official survey designed by the NBSC that is conducted annually by local statistics bureaus. Annual sample sizes of about 50,000 households are available. Households are surveyed in each city according to population size (e.g., there are 2,100 households surveyed in Beijing). Within each city, households are randomly sampled using stratified three-stage (neighborhood, housing complex, and household) PPS random sampling. More specifically, each household reports the total number of dwelling units it owns, and identifies its main residence as well as the occupancy status of all other units it owns as either “occasionally occupied", "leased out", or "other". To be conservative, we consider “occasionally occupied" and "other" units as vacant.

By law, it is the obligation of any household sampled to participate in the survey and to provide accurate information. Thus, survey data quality is perceived to be high. ${ }^{14}$ With support from the China Data Center at Tsinghua University, we were able to obtain the micro-level data in nine provinces between 2002 and 2009, including that for Beijing which is a provincial-level city. Figure 11's plot shows much lower vacancy rates, with the level across all nine provinces

\footnotetext{
${ }^{13}$ For example, they assumed that for households with three bedrooms, $99 \%$ had 1 unit and $1 \%$ had 2 units; for households with four bedrooms, $20 \%$ had 1 unit, $75 \%$ had 2 units, and 5\% had 3 units; for households with five bedrooms, $20 \%$ had 1 unit, $72 \%$ had 2 units, and $8 \%$ had 3 units; and so on. These assumptions were based on information on the breakdown of dwelling units by the number of bedrooms from the same census. They also assumed that a single household could occupy one unit at a time.

${ }^{14}$ For example, certain official statistics such as household disposal income and household expenditures on consumption reported are calculated using UHS data.
} 
increasing gradually from $3.9 \%$ in 2002 to $5.2 \%$ in 2009 . There is noteworthy heterogeneity in vacancy conditions across provinces, too. In 2009 for example, the vacancy rate was highest in the eastern province of Zhejiang (7.9\%), followed by Guangdong (5.5\%) and Liaoning (5.3\%). Beijing's vacancy rate was $5.1 \%$, with the western province of Gansu having the lowest rate at $1.3 \%$.

More recent vacancy rates can be imputed using our supply-demand change results if we are willing to use the 9-province aggregate to proxy for the nation. Based on the National Population Census, we can impute that the total number of urban households nationally was 197.95 million in 2009. Using the 5.2\% vacancy rate reported just above implies there were 10.86 million vacant units in urban areas that year $(197.95 /(1-5.2 \%) * 5.2 \% \approx 10.86)$, presuming one household occupies one unit. Based on the same procedures discussed in the previous sub-section, there was a net increase of 35.56 million households needing housing units during the four years between 2010 and 2013; on the supply side, the number of housing units increased by 41.31 million over the same time period. If all the 5.75 million units of excess supply were left vacant, then the vacancy rate increased to $7.0 \%$ by the end of 2013 $((10.86+5.75) /(208.81+41.31-12.98) \approx 0.070)$.

Both the level and the change need to be interpreted with care because Chinese economic conditions are fundamentally different from those in the U.S. and most other developed countries. As an emerging market experiencing rapid growth, the annual flow supply comprises a substantial share of the housing stock in China. For example, there were about 15.13 million housing units completed in 2013, which amounts to $5.7 \%$ of the total stock of about 265.74 million units at the end of that year in urban markets. In most cases, it would take the purchaser of a newly-built unit several months to furnish the unit before moving in. In addition, the share 
of uneconomic or dilapidated housing units is likely to be relatively high in China. The National Population Census in 2010 reports that $8.7 \%$ of the urban housing units were completed before 1979. That is before the reform era, which suggests that many of these units do not meet current quality standards demanded by urban households. Thus, many of them are likely to be left vacant. Factors such as these suggest the natural vacancy rate probably is higher in China than in developed markets such as the United States. That said, it is difficult to believe that the natural vacancy rate doubled over the past four years, so the recent jump in vacancies is mostly likely due to oversupply.

\section{Other Metrics: Price-to-Rent and Price-to-Income Ratios}

Other metrics such as the price-to-rent and price-to-income ratio can be computed for Chinese markets. Price-to-rent ratios for the same 12 major markets are plotted in Figure 12 dating back to the third quarter of $2009 .{ }^{15}$ The underlying data are averages of district-level prices (in the numerator) and rents (in the denominator), both of which are reported by a data vendor (www.cityre.cn) based on their collection of micro-level listing prices or rental prices information in the corresponding cities.

There is a very wide range of ratios, running from the low 20 s to just over 50 in the latest data from the last quarter of 2014. These are high values compared to the U.S. Recent decennial census data for July 2011 reports ratios from the mid-teens to the mid-40s for the thirty largest cities in the United States. Sixteen of those 30 areas have price-to-rent ratios below 20; another

\footnotetext{
${ }^{15}$ Data for all 35 major markets are available upon request.
} 
eight are between 20 and 30, with five cities in the thirties (New York City, Los Angeles, San Jose, Seattle, and Washington, DC), and only one above 40 (San Francisco at 44.1). ${ }^{16}$

Figure 12 shows little evidence of rising trends for this ratio, with Guangzhou being the exception. Its price-to-rent ratio has increased from just below 30 to just over 40 since 2009 . Other markets such as Shanghai, Tianjin, Chongqing, Wuhan and Dalian show flat trends, while there are significant declines in Hangzhou, Chengdu, and Xian. The latter cities are evidence that price-to-rent ratios can compress at least somewhat without prices themselves dropping at all. Beijing has the highest ratio (along with Shanghai) on average. It has been above 50 since 2013(1).

Poterba's (1984) user cost model of the rent-versus-own decision can be used in conjunction with price-to-rent data and information on the costs of occupying a housing unit to impute the breakeven price appreciation necessary for a new buyer to be indifferent between owning and renting each year. In the Chinese context, the user cost equation is given by $U C=r+m+\beta-\pi^{e}$,

where $U C$ represents the all-in costs of owning your housing unit for a given period of time, one year typically. Those costs are captured on the right-hand side of equation (3) by the capital cost $(r)$, maintenance and depreciation cost $(m)$, risk premium associated with housing investment $(\beta)$, and the expected housing appreciation $\left(\pi^{e}\right)$, with no property taxes in almost all localities. This formula is further simplified from the standard Poterba equation because there is no deductibility of mortgage interest in China.

Following Wu, Gyourko and Deng (2012), we use the 5-year deposit rate as the capital cost, presume maintenance and depreciation amount to $2.5 \%$ of house value annually, and

\footnotetext{
${ }^{16}$ See the story at http://seattlebubble.com/blog/2013/03/29/top-30-cities-price-to-rent-price-to-income-ratios-2011/ for more detail. The underlying U.S. Census data are downloadable at http://factfinder2.census.gov/faces/nav/jsf/pages/index.xhtml.
} 
impose a $2 \%$ risk premium. The first column in Table 9 lists the expected price appreciation needed for a buyer to be indifferent between owning and renting the unit given the other assumptions noted just above. The implied expected appreciation rates range from $4.5 \%$ (Xining) to $7.3 \%$ (Beijing) as of 2014(4).

Comparing the figures in columns 1 and 2 of Table 9 shows that in eleven cities the breakeven appreciation rate exceeds the average per annum compound rate realized over the previous nine years (Chengdu, Dalian, Haikou, Hangzhou, Hefei, Jinan, Nanchang, Ningbo, Taiyuan, Yinchuan, and Wuhan). Implied expectations seem to be more reasonable in other cities in the sense that they are within the range of recent experience in most markets. Of course, these results paint too optimistic a picture if we are underestimating on-going user costs of ownership. For example, if we use a 5-year loan rate in lieu of the deposit rate, then costs are about 150-200 basis points higher. In that case, another nine markets would have required price growth expectations above recent average appreciation. They include some of the largest markets in China: Harbin, Guiyan, Qingdao, Shenyang, Tianjin, and Xian.

There are no reasonable assumptions that do not leave the implied breakeven rate for Beijing well below its extremely high recent rates of price appreciation. However, that does not suggest that housing market price risk in the nation's capital is low. The contrary is the case, in fact, and the reason is because the market's price-to-rent ratio itself is so high. To better understand this, consider the potential outcome if expected appreciation in Beijing were for any reason to fall by only one percentage point from $7.3 \%$ to $6.3 \%$. In that case, the equilibrium user cost would increase from $1.9 \%$ to $2.9 \%$, implying a drop of price-to-rent ratio from 52.6 $(1 / 0.019 \approx 52.6)$ to $34.5(1 / 0.029 \approx 34.5)$, all else constant. Absent an offsetting increase in rents, this implies about a one-third drop in prices. Only modest drops in expected price growth (or 
rises in interest rates) are needed to generate potentially large price declines because they involve large percentage changes in (abnormally low) user costs. Large price declines need not occur, of course, if there are countervailing changes such as rising rents, and we see such cases in markets such as Hangzhou in Figure 12, where a falling price-to-rent ratio is associated with relatively flat prices and rapidly rising rents

Figure 13 presents analogous information on the price-to-income ratio. ${ }^{17}$ Caution is in order when interpreting these data, as there is substantial 'gray' income in China which biases up measured ratios (Wang and Woo, 2011; Deng, Wei and Wu, 2015). Changes in these ratios probably are more informative over time, as we have no reason to suspect large, high-frequency changes in reporting of income. With that caveat in mind, these figures show that price-toincome ratios are extraordinarily high in China. Five is a low number, with Beijing's being well over 10. Mortgage underwriting in the U.S. and many other developed countries considers anything above 3 to be potentially problematic. That said, conditions in China are quite different. Commercial banks typically consider $50 \%$ as the upper bound for the ratio of monthly debt service to monthly disposable income. Given a typical current mortgage with a 30 year term, a $30 \%$ down payment and a $6.55 \%$ interest rate, the maximum implied price-to-income ratio is about 9.4. Thus, price-to-income ratios in all markets but Beijing and Shanghai are consistent with current underwriting practices. That does not mean debt service is not high relative to income in China. It is. However, it is likely that other factors such as expected

\footnotetext{
${ }^{17}$ In the calculation, we use the average newly-built housing price and the average per capita disposable income, both reported by local statistics agency (either median house price or median income is available in China now). We then calculate the ratio between the price of a housing unit of 90 square meters in size and a household with three members (i.e., assuming that the per capita living space is 30 square meters).
} 
growth in urban incomes are perceived to make affordability less burdensome. ${ }^{18}$ Of course, this highlights how important future income growth is to the health of China's housing markets.

\section{IV. $\quad$ House Price Changes and Market Fundamentals: 35 Major Markets}

In this section, we estimate simple regression models to determine whether supply and demand fundamentals like those discussed above can help explain house price variation over time across Chinese cities. ${ }^{19}$ In doing so, we construct a panel data model using annual data between 2006 and 2013 for the 35 major cities listed above. Our price series is an update of the log change in real constant-quality prices from Wu, Deng and Liu (2014).

We begin with Table 10's summary results describing how much of real city-level house price growth can be explained by common versus city-specific factors. Column 1 reports the findings of a specification that regresses log real price change on year fixed effects. There is a strong common component in price growth, as year dummies can explain almost 40 percent of the variation in annual housing price growth. This is consistent with shifts in the macroeconomic environment, market sentiment, and/or the central government's housing market intervention policies playing an important role in all local housing markets. In contrast, column 2's results show that the explanatory power of city dummies is a much lower $12 \%$. The adjusted- $\mathrm{R}^{2}$ is so low that we cannot reject the null that city fixed effects are jointly equal to zero. The final column in Table 10 shows that these two factors are largely orthogonal to one another. When both sets of fixed effects are included on the right-hand side, the $\mathrm{R}^{2}$ is $50 \%$.

\footnotetext{
${ }^{18}$ Fang, et. al. (2015) report results consistent with this conclusion. In their study of 120 cities, they find that households from the lower end of the income distribution still are able to access financing and purchase homes, even in cities with high house price appreciation.

${ }^{19}$ See Ahuja et al (2010), Ren, Xiong and Yuan (2012), Zhang, Hua and Zhao (2012), Dreger and Zhang (2013), Chow and Niu (2014) for some other recent attempts on modeling housing price dynamics in major Chinese cities.
} 
We next investigate the role of relative supply-demand conditions. The first column of Table 11 adds controls for the ratio of unsold inventory held by developers to total sales in the relevant market during the previous year and for the ratio of presale permits to total sales in the previous year. $^{20}$ Both are negative and statistically significantly different from zero. However, only the inventory variable remains statistically significant when we add controls for the previous year's price level and rate of price growth. One possible reason is that developers could be adjusting the volume of new housing supply based on current housing prices or price changes. For example, during a downturn in the market, developers could choose to postpone some new projects and reduce new housing supply, which would at least partially reduce the magnitude of price drops. The impact of the inventory-to-sales variable declines modestly, but remains highly statistically significant.

Interestingly, price growth this year is significantly lower if the price level was higher last year (column 2 of Table 11). Thus, more expensive markets tend to mean revert in the sense their rate of appreciation will be lower. Column 3 of Table 11 then adds a number of other "fundamental" factors to the specification. On the demand side, two reflect exogenous demand shocks. Expected non-farm employment growth in the city is created using the method developed by Bartik (1991). This variable, epgrowt $_{i, t}$, is calculated as the weighted average of national industrial sector employment growth rates, where the weights reflect each city's share of that industry's aggregate employment. More specifically,

$$
\operatorname{epgrowth}_{i, t}=\sum_{j=1}^{18} \frac{e_{i, j, t-1}}{e_{i, t-1}} \cdot\left(\frac{\tilde{e}_{i, j, t}-\tilde{e}_{i, j, t-1}}{\tilde{e}_{i, j, t-1}}-\frac{e_{t}-e_{t-1}}{e_{t-1}}\right)
$$

\footnotetext{
${ }^{20}$ Both variables are calculated based on data provided by local housing authorities.
} 
where $e_{t}$ is the national employment level in all non-farm industries, $e_{i, j, t}$ is city $i$ 's employment in industry $j$ in year $t, \tilde{e}_{i, j, t}$ is the national employment level in industry $j$ outside of city $i$, and the $j$ subscript indexes the 18 non-farm employment sectors in China. ${ }^{21}$

A similar approach is taken to create another variable intended to reflect exogenous shocks in exports. That variable, exportgrowth ${ }_{i, t}$, is calculated as:

$$
\text { exportgrowt }_{i, t}=\frac{\text { export }_{i, t-1}}{\text { gdp }_{i, t-1}} \cdot\left(\frac{\text { expor } t_{i, t}-e \widetilde{x p o r} t_{i, t-1}}{\text { export }}\right) \text {, }
$$

where export $t_{i, t}$ is city $i$ 's export in year $t, g d p_{i, t}$ is city $i$ 's GDP in year $t$, and $\widetilde{\text { expor }} t_{i, t}$ is the national-level export outside of city $i$ in year $t$.

A credit conditions control is created in an analogous way. The growth in loans, loangrowth $_{i, t}$, is defined as

$$
\text { loangrowth } h_{i, t}=\frac{\operatorname{loan}_{i, t-1}}{\operatorname{gdp}_{i, t-1}} \cdot\left(\frac{\widetilde{\operatorname{loan}}_{i, t}-\widetilde{\operatorname{loan}}_{i, t-1}}{\widetilde{\operatorname{loan}}_{i, t-1}}\right)
$$

where $\operatorname{loan}_{i, t}$ is city $i$ 's total outstanding loan balance at the end of year $t$, and $\widetilde{\operatorname{loan}}_{i, t}$ is the national-level loan balance outside of city $i$ in year $t$.

We also experiment with a couple of supply side variables. One is the change in construction costs. The second is the annual residential-usage land supply volume from the CRLPI to reflect the effect of land supply. ${ }^{22}$

The findings from this expanded specification show that only the export variable consistently is statistically significant. A one standard deviation increase in expected export growth is associated with a 0.15 standard deviation higher rate of local house price appreciation. That is not nothing and signifies that a positive demand shock does lead to higher house price

\footnotetext{
${ }^{21}$ Unless otherwise stated, the data used in the rest of this section are provided by National Bureau of Statistics of China and local housing authorities.

${ }^{22}$ We never include land prices from the CRLPI because of the obvious endogeneity problems.
} 
appreciation. However, the $\mathrm{R}^{2}$ does not increase much from that reported in the first two columns.

More importantly economically is the fact that the inventory overhang variable remains statistically and economically significant. Its coefficient implies that a one standard deviation increase in normalized housing inventory would lead to a 0.45 standard deviation lower rate of real house price growth. Thus, supply overhangs as proxied for by rising unsold inventories relative to overall sales activity are associated with economically-meaningful lower rates of price growth the following year. This correlation remains strong even controlling for time and location fixed effects, as well as various other controls.

\section{Conclusion}

It is routine for people to ask whether Chinese housing is a 'bubble'. This paper does not attempt to answer that question, but does take on the challenge of assessing the riskiness of Chinese housing markets. That turns out to be substantially more difficult than the typical economist might believe. The first reason is that the data needed for any such analysis is limited. Hence, more accurate measurement of house prices themselves is the first answer to the question of 'what we need to know' in order to sensibly assess Chinese housing market risk. The official government price series are of lower quality than those created by private researchers, but data quality is improving and should continue to do so. Unfortunately, a very short time series for analysis cannot be improved upon by additional public or private research support. Only the passage of time will do in that respect.

In the meantime, insight into market risk still can be gleaned from a careful analysis of supply and demand conditions. We looked at a number of metrics and came to the following 
conclusions: (1) there is substantial heterogeneity in the volume of supply-demand imbalances across markets, both over time and in the shorter run; (2) high price level and price appreciation rate markets such as Beijing and others on the east coast do not look to be oversupplied by our metrics; there are a number (much more than a handful) of markets, primarily off the coast, where oversupply looks to be substantial by one or more measures; even absent a negative economic shock, these markets look very risky, as we would expect weak housing market fundamentals to lead to weak or negative price growth no matter what; empirically, we report a correlation showing that a one standard deviation higher inventory overhang in a local market is associated with nearly a one-half standard deviation lower future growth rate of real prices; (3) even markets such as Beijing with strong measured fundamentals should be considered risky because housing units there trade at very high multiples of rent; it only takes a modest downward shift in expectations (or a commensurate increase in interest rates) to generate sharp asset value declines when a market is 'priced to perfection'; naturally, a true negative shock in terms of a policy intervention or a further downshift in economic growth would compound the problem.

There are other factors that affect risk which are beyond the scope of this already lengthy paper. Debt is one example. Negative equity appears to have played a critical factor in the U.S. housing bust, but there appears to be substantial equity in the Chinese residential housing system. If there is hidden leverage in the system, that would be problematic, but we leave that possibility to other research. 


\section{Selected References}

Ahuja, A, Cheung, L, Han, G, et al (2010). “Are House Prices Rising too Fast in China”, IMF Working Paper WP/10/274.

Ambrose, B, Deng, Y, and Wu, J (2015). "Understanding the Risk of China's Local Government Debts and its Linkage with Property Markets”, SSRN working paper \#SSRN 2557031.

Bartik, T (1991), Who Benefits from State and Local Economic Development Policies? Upjohn Press, Kalamazoo.

Cao, J, Huang, B, and Lai, R (2015), "On the Effectiveness of Housing Purchase Restriction Policy in China: A Difference in Difference Approach”, SSRN working paper \#2584275.

Chen, J, Guo, F, and Wu, Y (2011), “One decade of urban housing reform in China: Urban housing price dynamics and the role of migration and urbanization, 1995-2005", Habitat International, 35(1): 1-8.

Chen, J and Han, X (2014), "The Evolution of the Housing Market and its Socioeconomic Impacts in the Post - Reform People's Republic of China: A Survey of the Literature", Journal of Economic Surveys, 28(4): 652-670.

Chow, G and Niu, L (2014). "Housing Price in Urban China as Determined by Demand and Supply", working paper, Princeton University.

Deng, Y, Gyourko, J, and Wu, J (2012). "Land and House Price Measurement in China," in: Property Markets and Financial Stability, Heath, A, Packer, F and Windsor, C, eds., Bank of International Settlement and Reserve Bank of Australia.

Deng, Y, Gyourko, J, and Wu, J (2014). "The Wharton/NUS/Tsinghua Chinese Residential Land Price Indexes (CRLPI) White Paper,” working paper, National University of Singapore.

Deng, Y, Wei, S, and Wu, J (2015). "Estimating the Unofficial Income of Officials from Housing Purchases: The Case of China," working paper, National University of Singapore.

Dreger, C and Zhang, Y (2013). "Is There a Bubble in the Chinese Housing Market", Urban Policy and Research, 31(1): 27-39.

Du, Z, and Zhang, L (2015). "Home-purchase Restriction, Property Tax and Housing Price in China: A Counterfactual Analysis", Journal of Econometrics, forthcoming.

Fan, Z, Tao K and Xiao, S (2015). “Credit Risk of Local Government Financing Vehicles in China", unpublished working paper, CCER, Peking University.

Fang, H, Gu, G, Xiong, W, and Zhou, L (2015). "Demystifying the Chinese Housing Boom”, NBER Working Paper 21112, April 2015. 
Gan, Li (2012). Research Report of China Household Finance Survey 2012. Southwestern University of Finance and Economics Press.

Garriga, C, Wang, P, and Tang, Y (2014). "Rural-Urban Migration, Structural Transformation, and Housing Markets in China", St Louis Fed Working Paper 2014-028A.

Guo, X, Zheng, S, Geltner, D, and Liu, H (2014). “A New Approach for Constructing Home Price Indices: The Pseudo Repeat Sales Model and Its Application to China", Journal of Housing Economics, 25(1): 20-38.

Huang, D, Leung, C, and Qu, B (2015). "Do bank loans and local amenities explain Chinese urban house prices?", China Economic Review, 34(1): 19-38.

Poterba, J (1984). "Tax Subsidies to Owner-occupied Housing: An Asset Market Approach”, Quarterly Journal of Economics, 99(4): 729-752.

Ren, Y, Cong, X, and Yuan, Y (2012). "House Price Bubbles in China", China Economic Review, 23(4): 786-800.

Shen, L (2012). “Are House Prices too high in China?” China Economic Review, 23(4): 12061210 .

Tao, K (2015). “Assessing Local Government Debt Risks in China: A Case Study of local Government Financial Vehicles", unpublished working paper.

Wang, S (2011). "State Misallocation and Housing Prices: Theory and Evidence from China", American Economic Review, 101(5): 2081-2107.

Wang, X and Woo, W (2011). "The Size and Distribution of Hidden Household Income in China," Asian Economic Papers, 10(1): 1-26.

Wang, S, Chan, S, and Xu, B (2012). "The Estimation and Determinants of the Price Elasticity of Housing Supply: Evidence from China," Journal of Real Estate Research, 34(3): 311-344.

Wang, Z and Zhang, Q (2014). "Fundamental factors in the housing markets of China," Journal of Housing Economics, 25(1): 53-61.

Wu, J, Gyourko, J, and Deng, Y (2012). "Evaluating Conditions in Major Chinese Housing Markets", Regional Science and Urban Economics, 42 (3): 531-543.

Wu, J, Deng, Y, and Liu, H (2014). "House Price Index Construction in the Nascent Housing Market: The Case of China", Journal of Real Estate Finance and Economics, 48(3): 522545. 
Wu, G, Feng, Q, and Li, P (2014). “Does local governments' budget deficit push up housing prices in China?", China Economic Review, forthcoming.

Zhang, Y, Hua, X, and Zhao, L (2012). "Exploring determinants of housing prices: A case study of Chinese experience in 1999-2010”, Economic Modelling, 29(6): 2349-2361. 
Appendix 1: Calculation of the Ratio between Changes in Housing Demand and Supply

\section{$\underline{\text { Demand Side Indicator }}$}

The demand side indicator measures the number of family households needing new housing units in the city during the decade between 2001 and 2010. It is important to note that the definition of "family household" in China is not consistent with that in other countries like U.S. In China, all the three following cases would be counted as one family household in the National Population Census (NPC): (1) if one family occupies one dwelling unit, it would be counted as one family household; (2) if two or more families share one dwelling unit, but each of them occupies at least one bedroom, each of them would be treated as one family household; (3) if one person occupies one dwelling unit (or one room in the unit) alone, he/she would also be counted as one family household.

The demand side indicator is calculated as the sum of two components: (1) net increase in family households living in the urban area and (2) urban family households previously living in units that were demolished.

(1) Net increase of family households living in the urban area

The first component measures the net increase of family households living in the urban area of the city between 2000 and 2010, which may come from either the formation of new families, or immigration of households from other cities or from rural areas (of the same or other cities).

The number of urban family households are directly available in the NPCs in both 2000 and 2010: from the $2000 N P C$, we obtain the total number of family households living in the urban area of the city on Nov $1^{\text {st }}, 2000$, both with and without local "hukou" (residence registration); similarly, the corresponding figure for Nov $1^{\text {st }}, 2010$ is available in the $2010 N P C$. Based on these two numbers we calculate the net increase in the number of family households during the decade. In the city of Beijing for example, there were 3,231,319 households living in its urban area as reported in the $2000 \mathrm{NPC}$, and 5,803,085 in 2010, implying a net increase of $2,571,766(5,803,085-3,231,319=2,571,766)$ households.

One potential problem here is that the boundary of the "urban area" in a city is not necessarily consistent between 2000 and 2010. Due to the continuous urbanization, some villages at the city edge might be defined as a "rural area" in the $2000 \mathrm{NPC}$, but then urbanized 
during the decade and so redefined as an "urban area" in the 2010 NPC. Such a redefinition would lead to an increase in urban households, but some households in these "villages" might actually live in exactly the same units in 2000 and 2010. Therefore, it might result in an upward bias in the demand side indicator.

We try to correct for this bias based on data of households reported as living in a rural area. Using Beijing as an example, in the 2000 NPC there were 2,533,459 persons with local hukou living in its rural area. Without any population migration or redefinition of urban area, these $2,533,459$ persons ought to increase to $2,573,766$ in 2010 , given the natural growth rate of $1.591 \%$ in Beijing during the decade; however, the actual population living in the rural area of Beijing reported in the 2010 NPC was 1,908,652, which implies that there were 665,114 $(2,573,766-1,908,652=665,114)$ persons which were either re-defined as living in the urban area, or moved to the urban area of Beijing, or moved out of the city. According to the NPC data, during the decade there were 209,910 persons who previously lived in the rural area of Beijing but moved to other cities or the urban area of Beijing, which implies that 455,204 (665,114$209,910=455,204$ ) persons were re-defined as living in the urban area. Presuming three people per household, this works out to 150,481 households. Therefore, the actual number of increase in urban households is 2,421,285 $(2,571,766-150,481=2,421,285)$.

(2) Urban family households with previous dwelling units demolished

The second component measures the number of family households living in the urban area (as of the 2000 NPC) whose dwelling units were demolished in the urban regeneration process over the decade. These households need to purchase or rent a new unit and thus also contribute to the demand for new housing supply. Unfortunately, for almost all cities this number is not directly available, but can only be imputed indirectly. The procedures are as follows, and again we take Beijing as the example (Table A-1).

1) In both the 2000 and 2010 NPCs, about $10 \%$ of the family households were sampled to provide additional information, including the building age of their current dwelling units. We use this information to calculate the demolition rate for each building age category. For example, there were 4,096,844 family households in Beijing (both urban and rural area) in 2000 , of which 402,717 households were sampled to provide additional information. Of these 402,717 households, 18,425 reported that their current dwelling units were built before 1949, which implies that there were about $187,438(18,425 / 402,717 * 4,096,844 \approx 187,438)$ family 
households in Beijing with dwelling units built before 1949. Using the same methodology, we compute that there were only 7,913 such households in 2010. This suggests that there were 106,752 dwelling units of pre-1949 vintage demolished during the decade, or a demolition rate of $56.95 \%(106,752 / 187,438 \approx 0.5695)$.

2) Analogous demolition rates are calculated for other vintages. For the vintages of "1990-1999" and "after 2000", we assume that the demolition rates are $1 \%$ and $0 \%$, respectively, according to a report by Institute of Real Estate Studies, Tsinghua University.

3) In the 2010 NPC the building age category information is also available for family households living in the urban area. With the assumption that the demolition rate did not significantly differ between urban and rural areas, we can use that figure to impute the number of households with units demolished in each category. For example, in 2010 there were 76,584 urban family households with dwelling units built before 1949, and according to the above calculation the demolition rate was 56.95\%. This implies that there were 101,327 (76,584 / (1 $56.95 \%) * 56.95 \% \approx 101,327$ ) households in this category with units demolished during the decade.

In total, we estimate that housing units of 393,159 urban households in Beijing were demolished during the decade.

Aggregated number

Based on these calculations, the aggregated demand for new housing units in Beijing is 2.81 million units.

\section{Supply Side Indicator}

The supply side indicator measures the number of housing units completed and available for family households in the city during the decade. There are two components included here: (1) units developed by firms or institutions; and (2) units built by households themselves.

(1) Units developed by firms or institutions

We start with the total floor area of housing completed. In Beijing, there were 209.69 million sq.m. of housing completed between Nov 1st, 2000 and Oct 30th, 2010, including private housing developed by housing developers, public housing developed by governments, 
institutional housing developed by universities or other institutions, etc., but excluding any informal housing or units built by households themselves.

However, not all the 209.69 million sq.m. are available for the family households. Besides the family households, there is also another group of "non-family" households reported in the NPCs. These so-called "non-family households" refer to those living in one room but are legally unrelated. Mainly, they include three groups: (1) those who rent and live in dormitories provided by universities, high schools, factories, construction sites, or other institutions; (2) those who rent and share one room; (3) unmarried couples.

We deduct their demand from the 209.69 million sq.m. In Beijing, there were totally 1,443,186 persons defined as non-family households in the 2000 NPC. Based on the building code for institutional housing in 2000, we assume that the per capita living space for them is 6.5 sq.m. in 2000, and thus they need about 9.38 million sq.m. of housing in aggregate. By 2010, the population of this group increased to 2,892,968 persons and the standard for per capita living space also increased to 7.0 sq.m., and so they need about 20.25 million sq.m. of housing. Therefore, their housing demand increased by $10.87(20.25-9.38=10.87)$ million sq.m. during the decade. Presuming that demand was fully satisfied implies $198.60(209.47-10.87=198.60)$ million sq.m. of new housing supply available for family households.

Finally, we need to covert the floor area to units. According to the 2010 NPC $(10 \%$ sample survey), in Beijing there were 240,996 urban household respondents whose current units were built after 2000, and the total floor area was 19.69 million sq.m., implying an average unit size of 81.73 sq.m. This helps us to get the final result of about $2.43(198.60 / 81.73 \approx 2.43)$ million units completed and available for family households during the decade.

(2) Units built by households

According to the sample survey mentioned above, in 2000 there were 512,298 urban households in Beijing who built their own units. In addition, there were 150,481 rural households re-defined as urban households, and we assume each household occupied one housing unit. Given the average demolition rate of $11.08 \%$ mentioned above, the number would decrease to $589,374((512,298+150,481) *(1-11.08 \%) \approx 589,374)$ in 2010 . The corresponding number reported in the 2010 NPC was 429,589 in 2010. Thus, in Beijing we believe that the sector of self-built housing units did not contribute to the flow supply during the decade, but it 
does not necessarily apply to other cities. In particular, this sector is usually more important in less developed cities.

(3) Aggregate number

Based on the above calculation, we can get the aggregated supply for new housing units. For Beijing, the result is 2.43 million units.

\section{Supply-Demand Ratio}

Based on the above results we can compare the supply-demand ratio. In Beijing, we get the result of $82.88 \%(2.43 / 2.81 \approx 0.8288)$.

\section{Updating the Calculation to Post-2010 Years}

We also update the supply-demand ratio calculation to 2011 and 2012. Without the detailed data provided by a $N P C$, we have to make several assumptions as described below.

(1) For the component of "net increase of family households living in the urban area", we adopt the estimate of urban population at the end of each year (i.e., 2011 and 2012) provided by the relevant local statistic agency, and assume that the average urban household size kept changing in the same direction and at the same speed as between 2001 and 2010.

(2) For the component of "urban family households with previous dwelling units demolished", we apply the demolition rate for each building age category calculated based on the period 2001-2010 to the housing stock in 2010, and assume that the volume of demolition would be evenly distributed between 2011 and 2020.

(3) For the component of "units developed by firms or institutions", we adopt the volume of annual housing completion reported by the relevant local statistic agency, and assume that both the percentage for non-family households and the average housing unit size were consistent with the corresponding numbers in 2001-2010.

(4) For the component of "units built by households", we assume that its ratio against units developed by firms or institutions kept stable, as between 2001 and 2010. 
Table A-1: Imputing of Urban Households with Previous Dwelling Units Demolished

\begin{tabular}{|c|c|c|c|c|c|c|c|c|c|}
\hline \multicolumn{10}{|c|}{ A. Households in both Urban and Rural Areas } \\
\hline & & All & Before 1949 & $1950-1959$ & $1960-1969$ & $1970-1979$ & 1980-1989 & 1990-1999 & After 2000 \\
\hline \multirow{2}{*}{$\begin{array}{c}2000 \\
\text { Census }\end{array}$} & Sample & 402,717 & 18,425 & 21,406 & 16,858 & 43,577 & 148,539 & 153,912 & - \\
\hline & Total & $4,096,844$ & 187,438 & 217,763 & 171,497 & 443,309 & $1,511,089$ & $1,565,748$ & - \\
\hline \multirow{2}{*}{$\begin{array}{c}2010 \\
\text { Census }\end{array}$} & Sample & 655,178 & 7,913 & 13,829 & 12,683 & 35,520 & 135,322 & 182,140 & 267,771 \\
\hline & Total & $6,680,552$ & 80,685 & 141,008 & 129,323 & 362,181 & $1,379,817$ & $1,857,199$ & $2,730,339$ \\
\hline \multicolumn{2}{|c|}{ Change } & - & 106,752 & 76,755 & 42,174 & 81,128 & 131,272 & - & - \\
\hline \multicolumn{2}{|c|}{ Demolishing Rate } & - & $56.95 \%$ & $35.25 \%$ & $24.59 \%$ & $18.30 \%$ & $8.69 \%$ & $1.00 \%$ & $0.00 \%$ \\
\hline \multicolumn{10}{|c|}{ B. Households in Urban Area } \\
\hline & & All & Before 1949 & $1950-1959$ & 1960-1969 & $1970-1979$ & 1980-1989 & 1990-1999 & After 2000 \\
\hline \multirow{2}{*}{$\begin{array}{c}2010 \\
\text { Census }\end{array}$} & Sample & 567,545 & 7,490 & 13,061 & 10,611 & 27,106 & 108,066 & 160,245 & 240,966 \\
\hline & Total & $5,803,085$ & 76,584 & 133,547 & 108,496 & 277,156 & $1,104,963$ & $1,638,487$ & $2,463,851$ \\
\hline \multicolumn{2}{|c|}{ Demolishing Rate } & - & $56.95 \%$ & $35.25 \%$ & $24.59 \%$ & $18.30 \%$ & $8.69 \%$ & $1.00 \%$ & $0.00 \%$ \\
\hline \multicolumn{2}{|c|}{ Demolished } & 393,159 & 101,327 & 72,694 & 35,382 & 62,082 & 105,123 & 16,550 & 0 \\
\hline
\end{tabular}




\section{Figure 1: 35 Major Cities Covered}

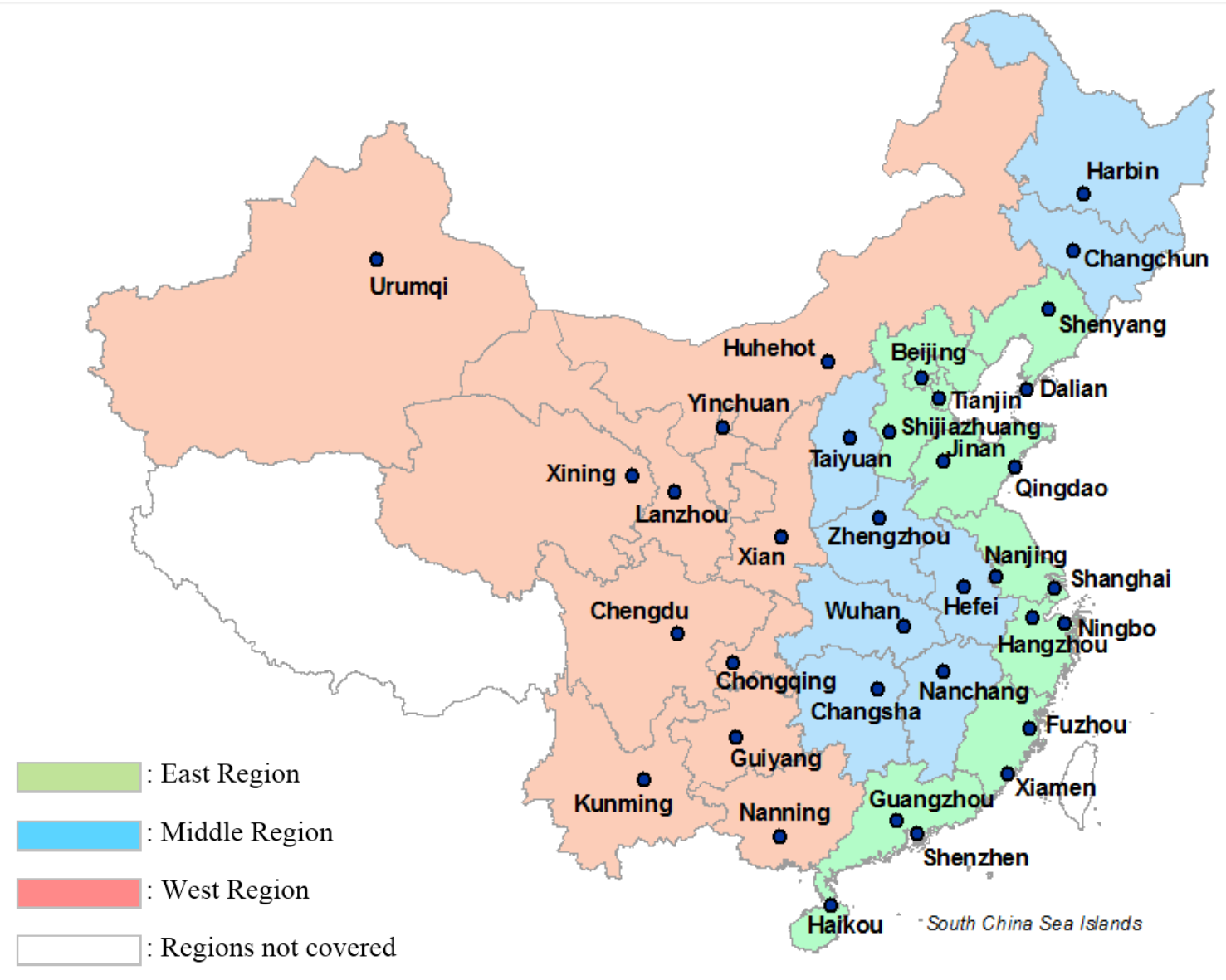


Figure 2: Chinese National Real Residential Land Price Index, 35 Markets,

Constant Quality Series (Quarterly: 2004q1 - 2014q4)

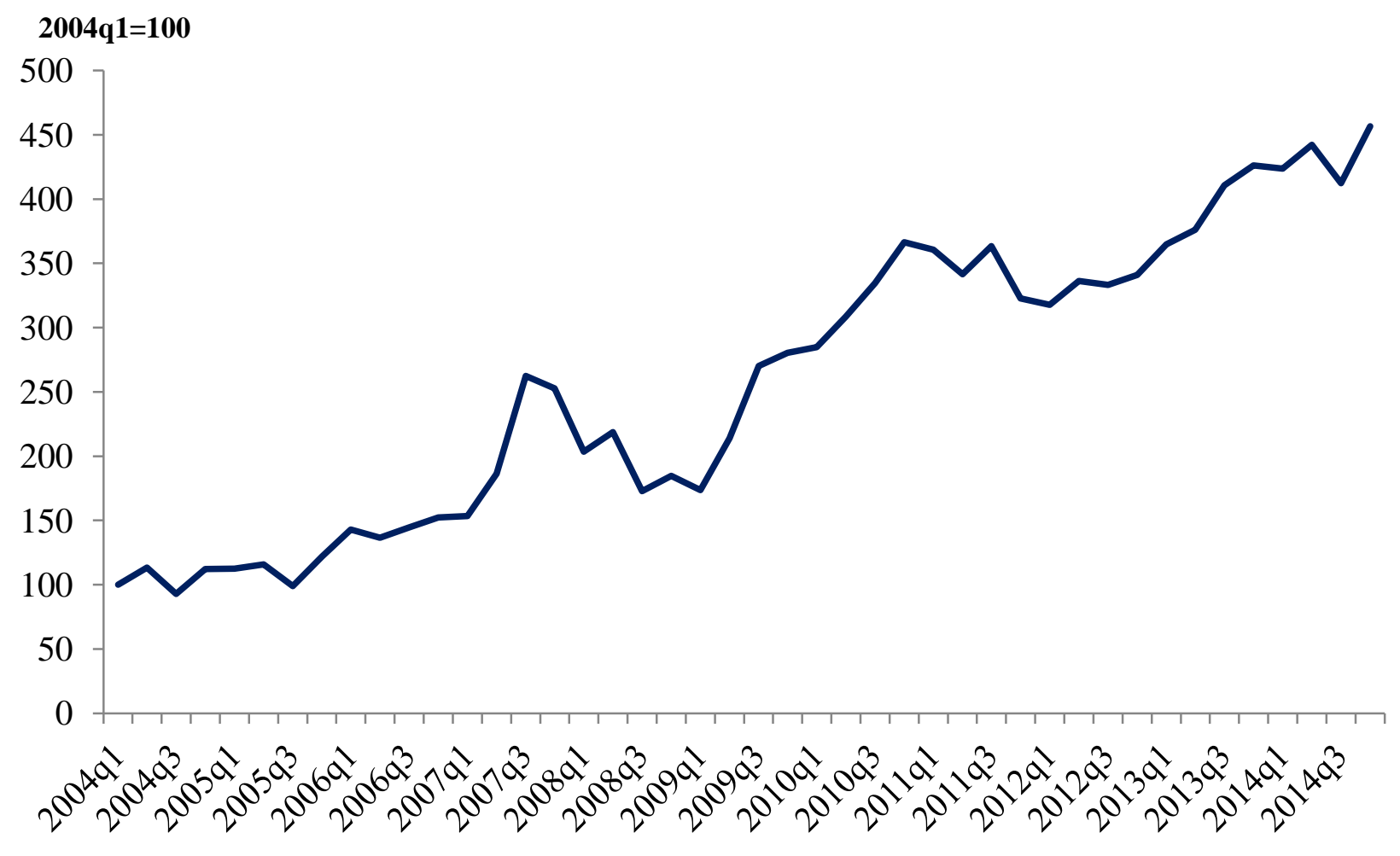


Figure 3: Chinese Regional Real Residential Land Price Indexes-

East, Middle and West Regions, Constant Quality Series, 2004h1-2014h2

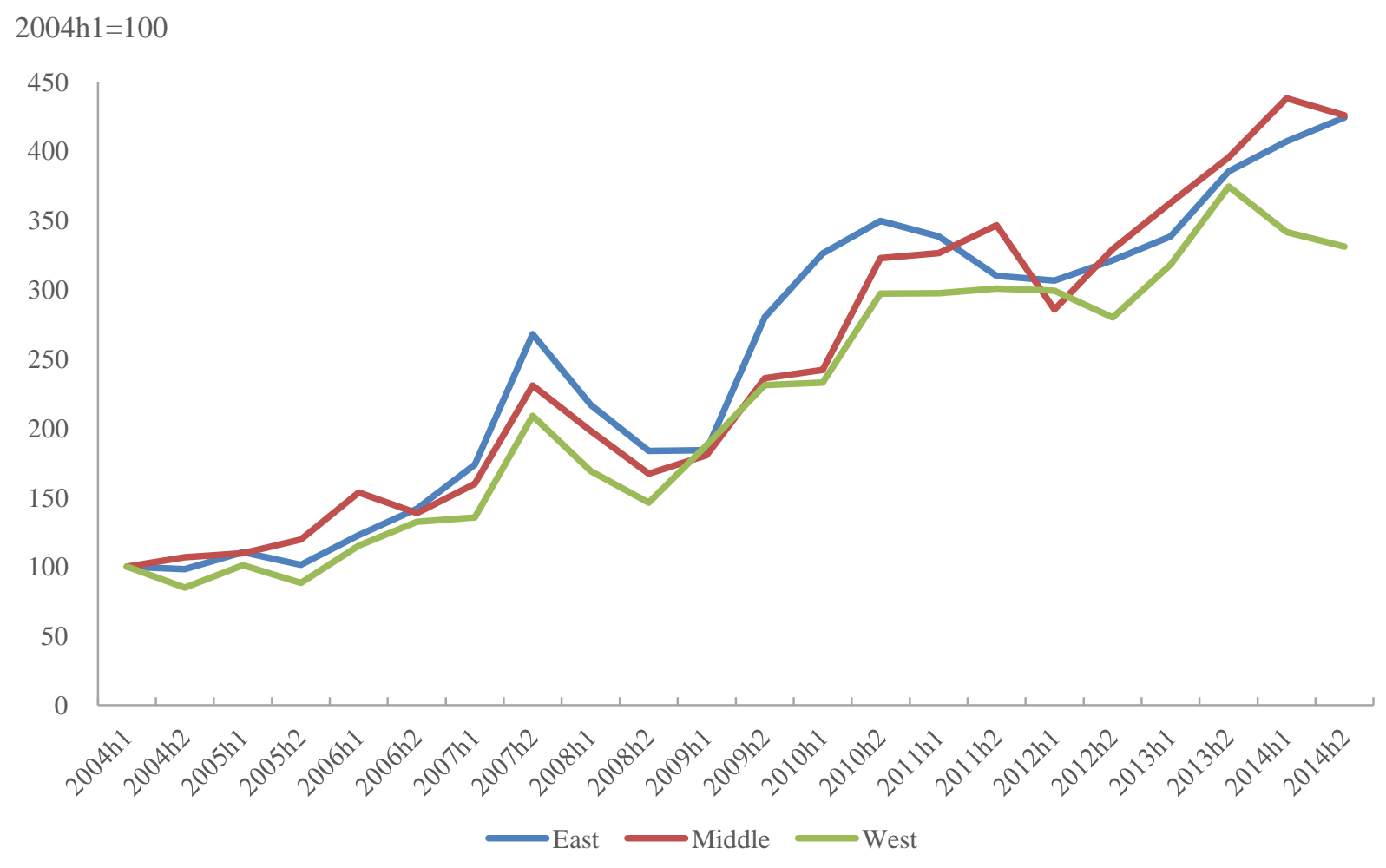


Figure 4: Real Residential Land Price Indexes in 12 Markets,

Constant Quality Series, 2004-2014
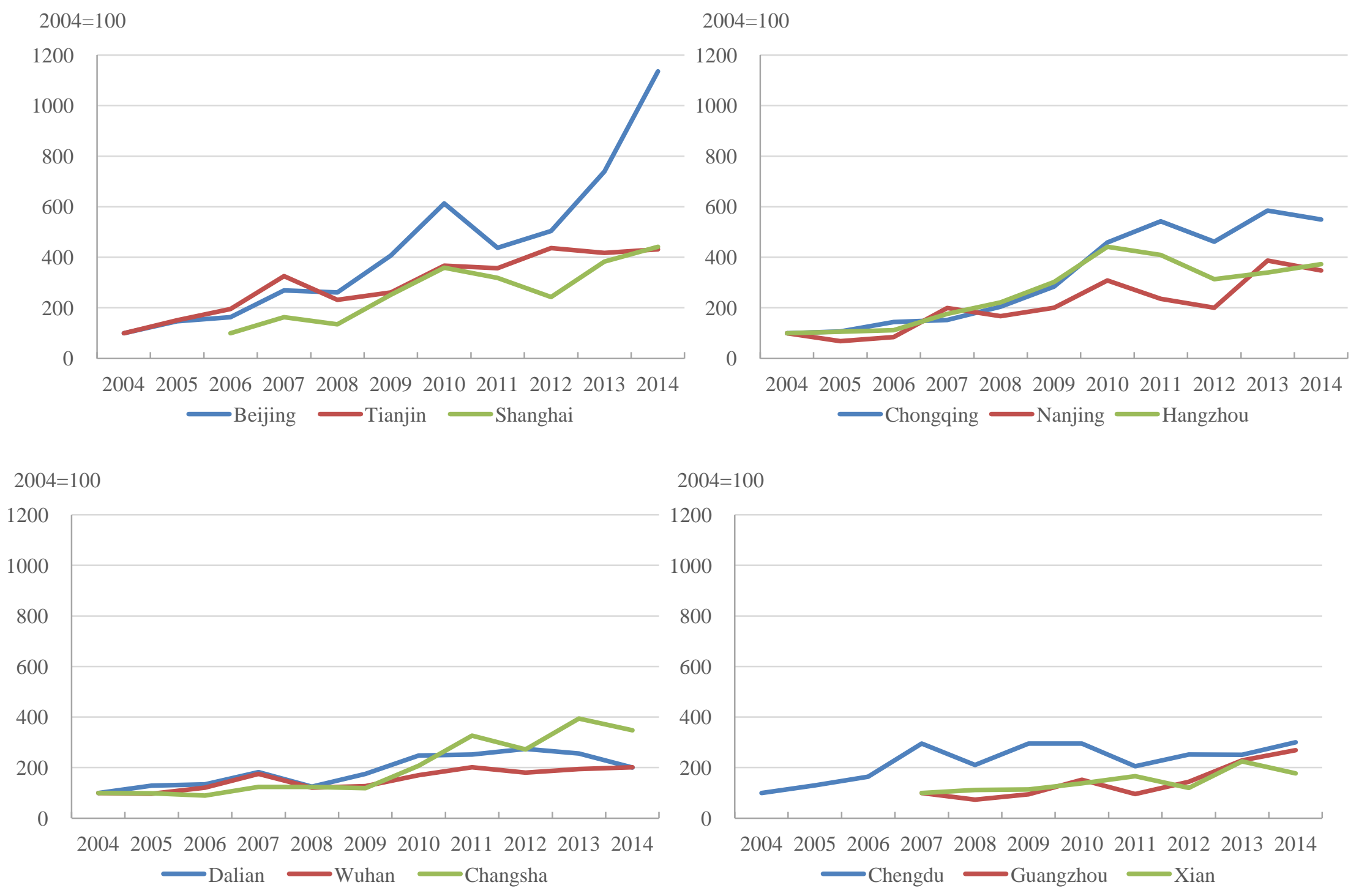
Figure 5: Quarterly Land Parcel Sales in China (35 Market Aggregate) 2004(1)-2014(4)

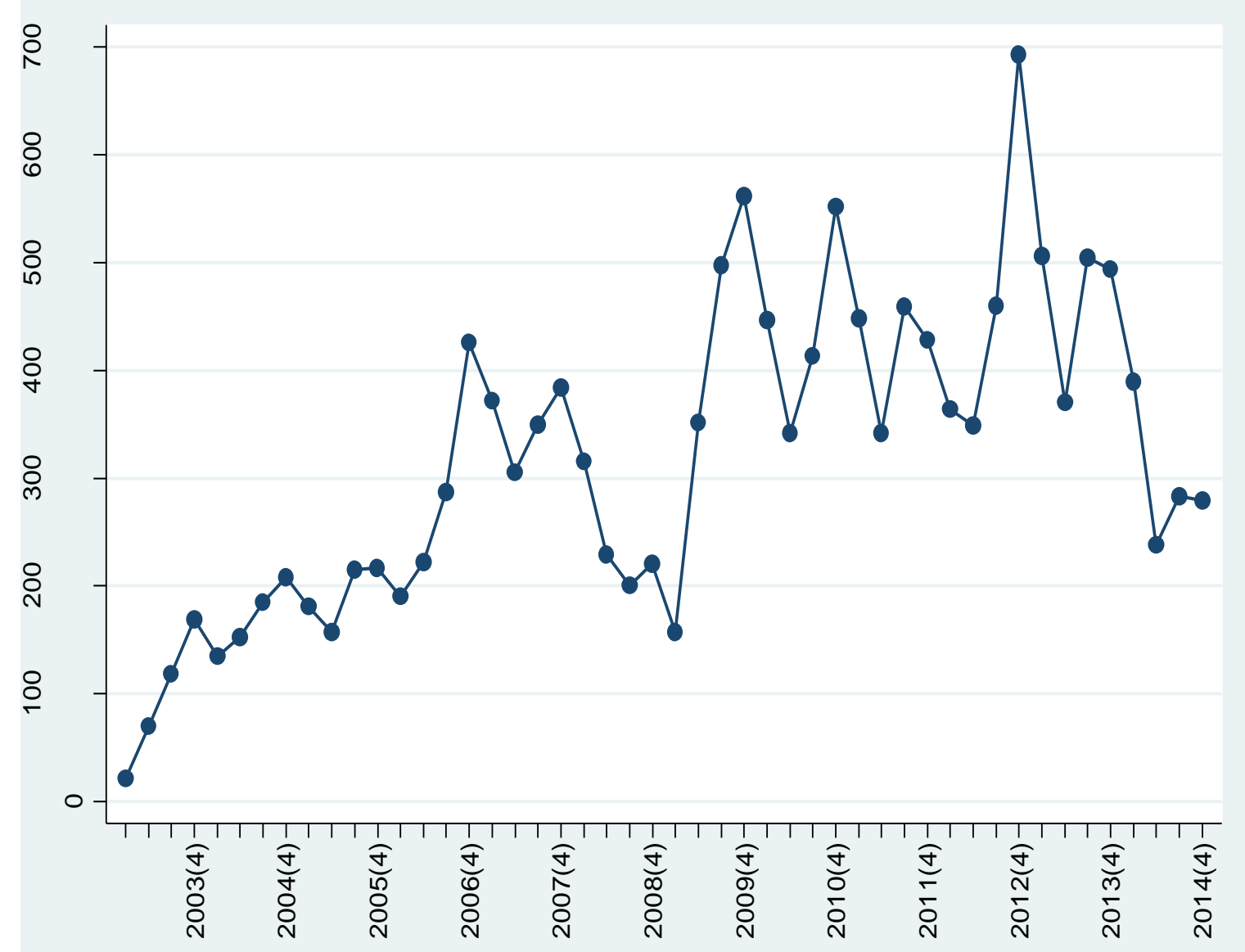


Figure 6: Year-Over-Year Growth in Floor Space Sold,

Newly-Built Housing Units, 2007(1)-2014(4)

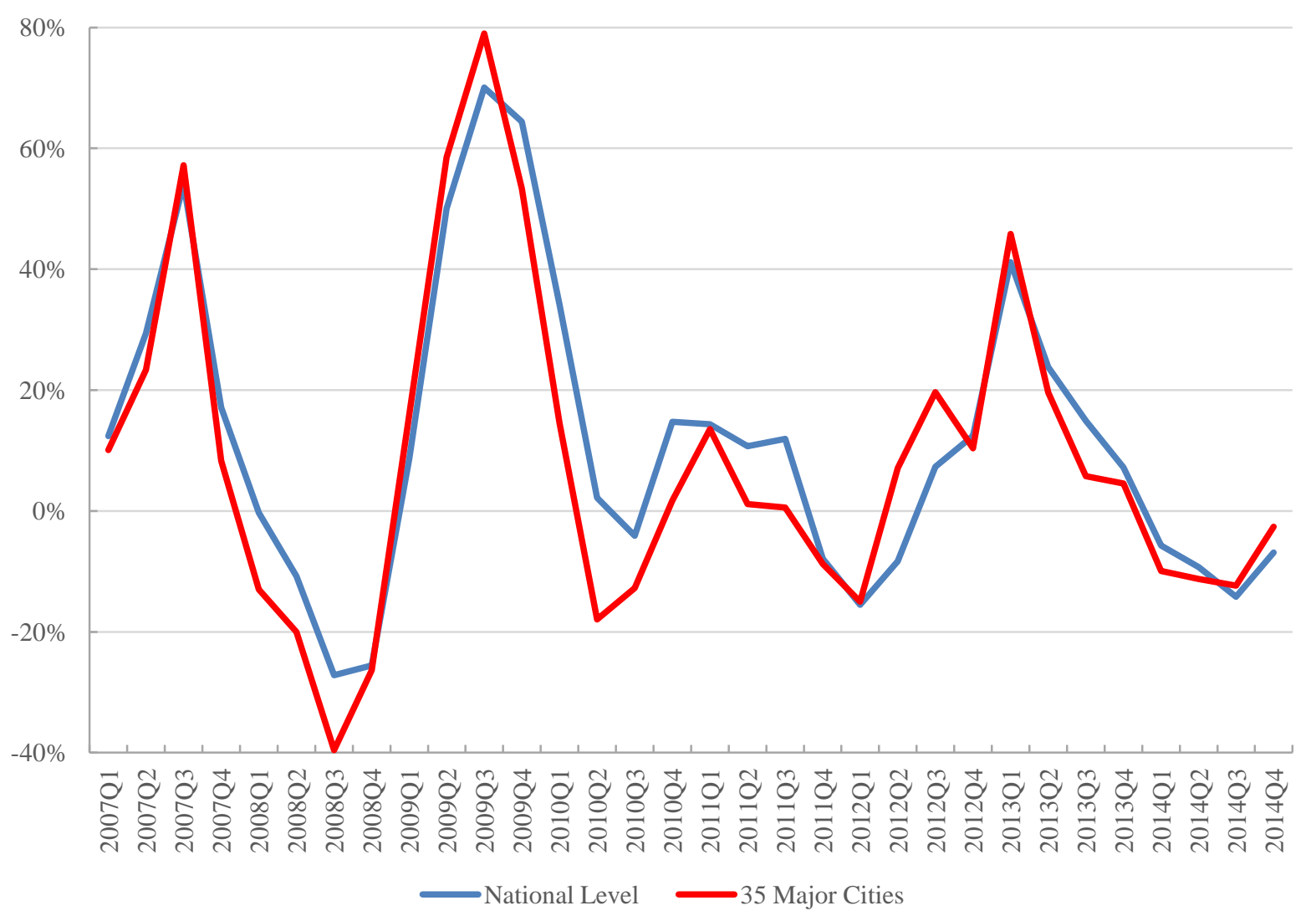


Figure 7: Transactions Volume and Prices in the U.S. Housing Market

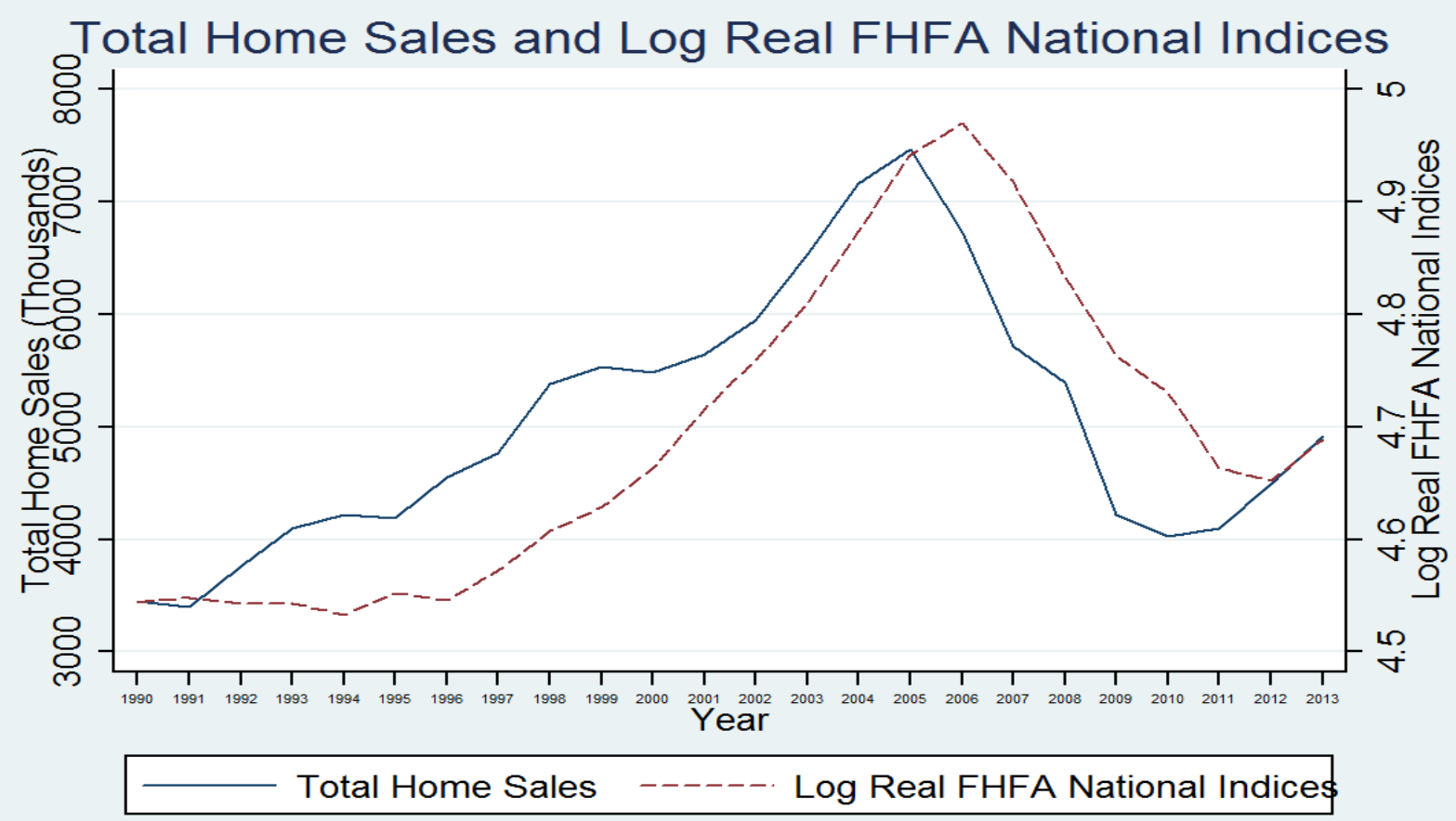

Note: the 2013 value for total home sales is preliminary as of Aug 2014 
Figure 8: Annual New Housing Supply As a Share of the 2010 Stock in 12 Major Markets
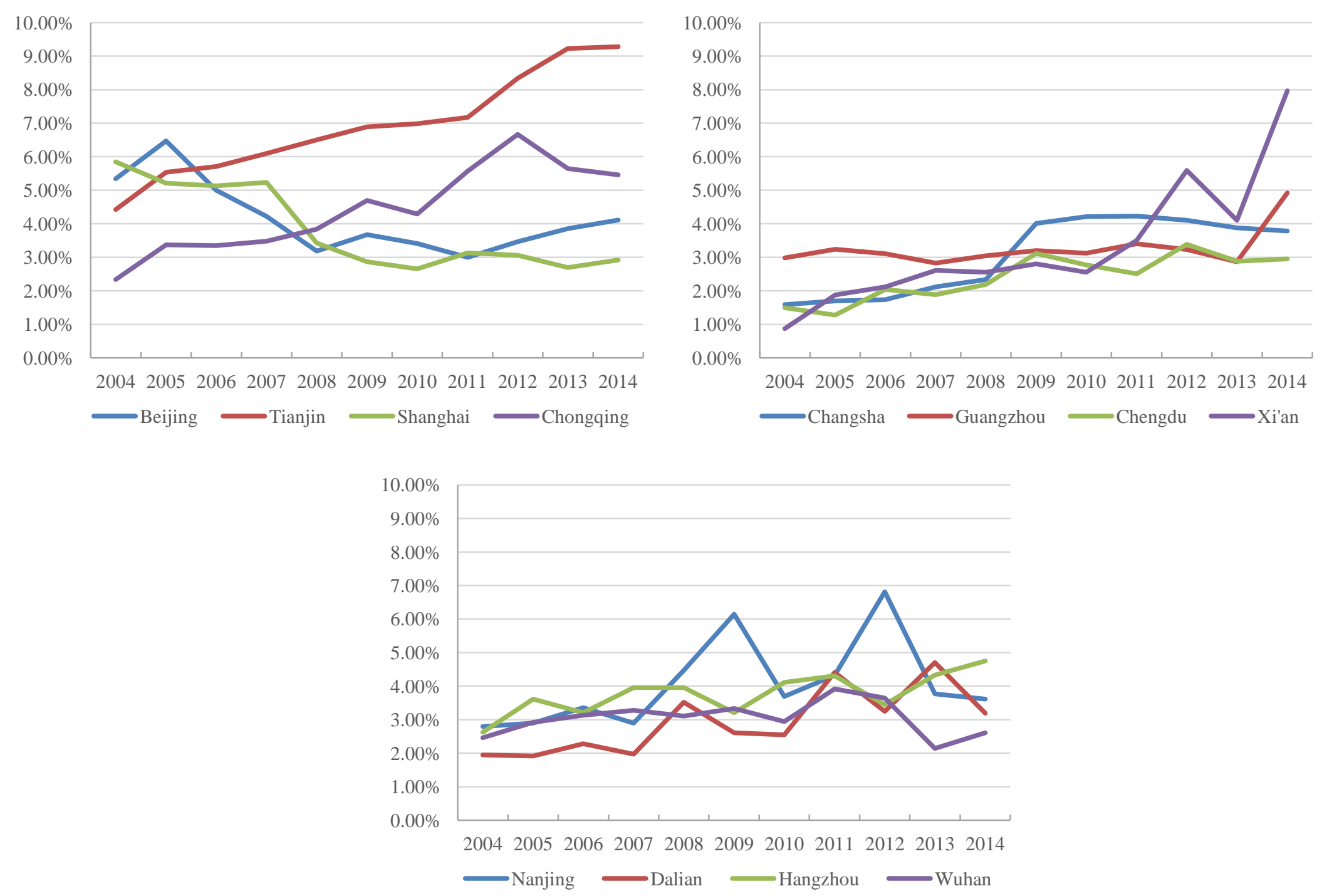
Figure 9: Unsold Inventory Held by Developers As a Share of Sales Volume in 12 Major Markets
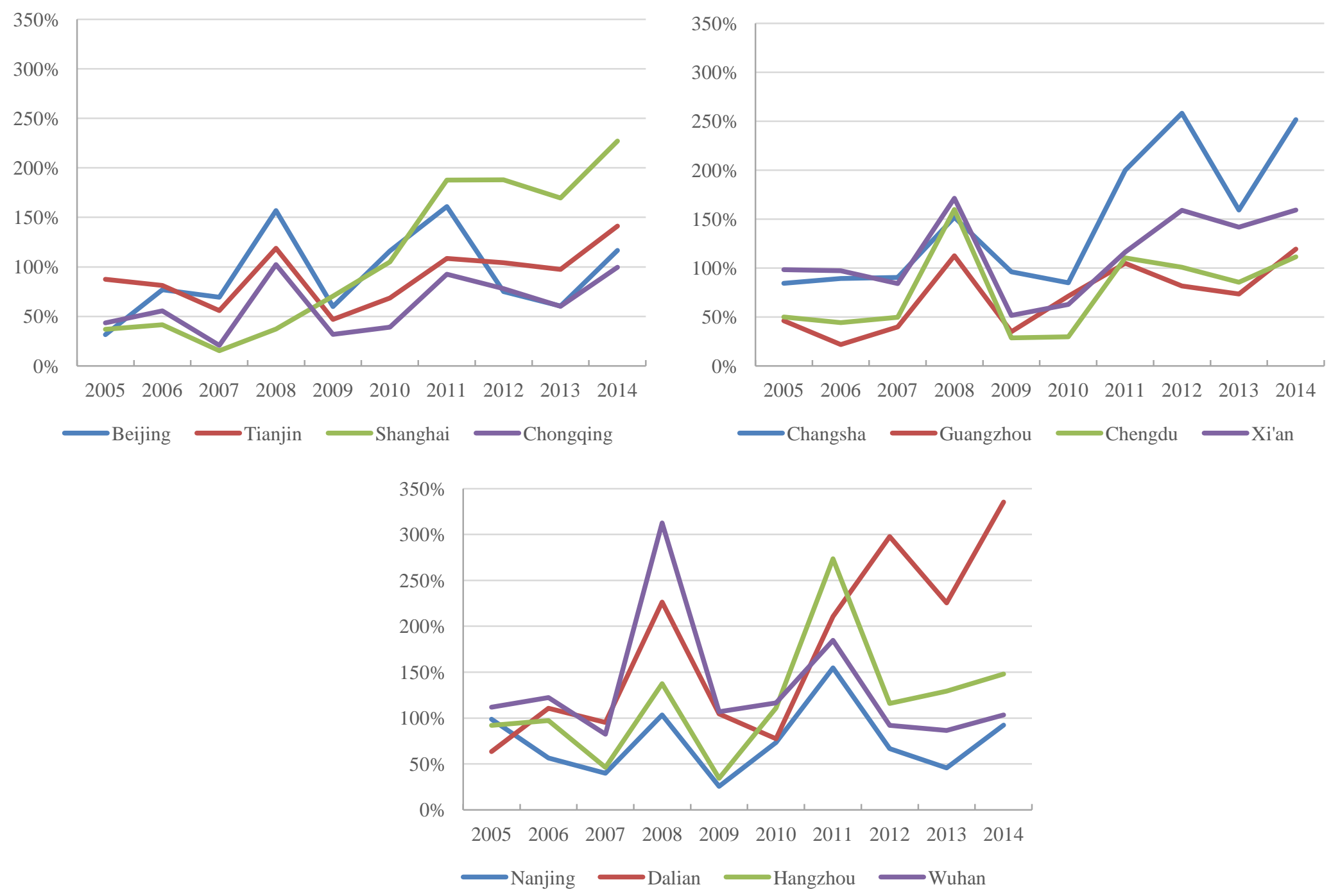
Figure 10: Aggregate Space Delivered in Housing Starts, 35 Major Markets

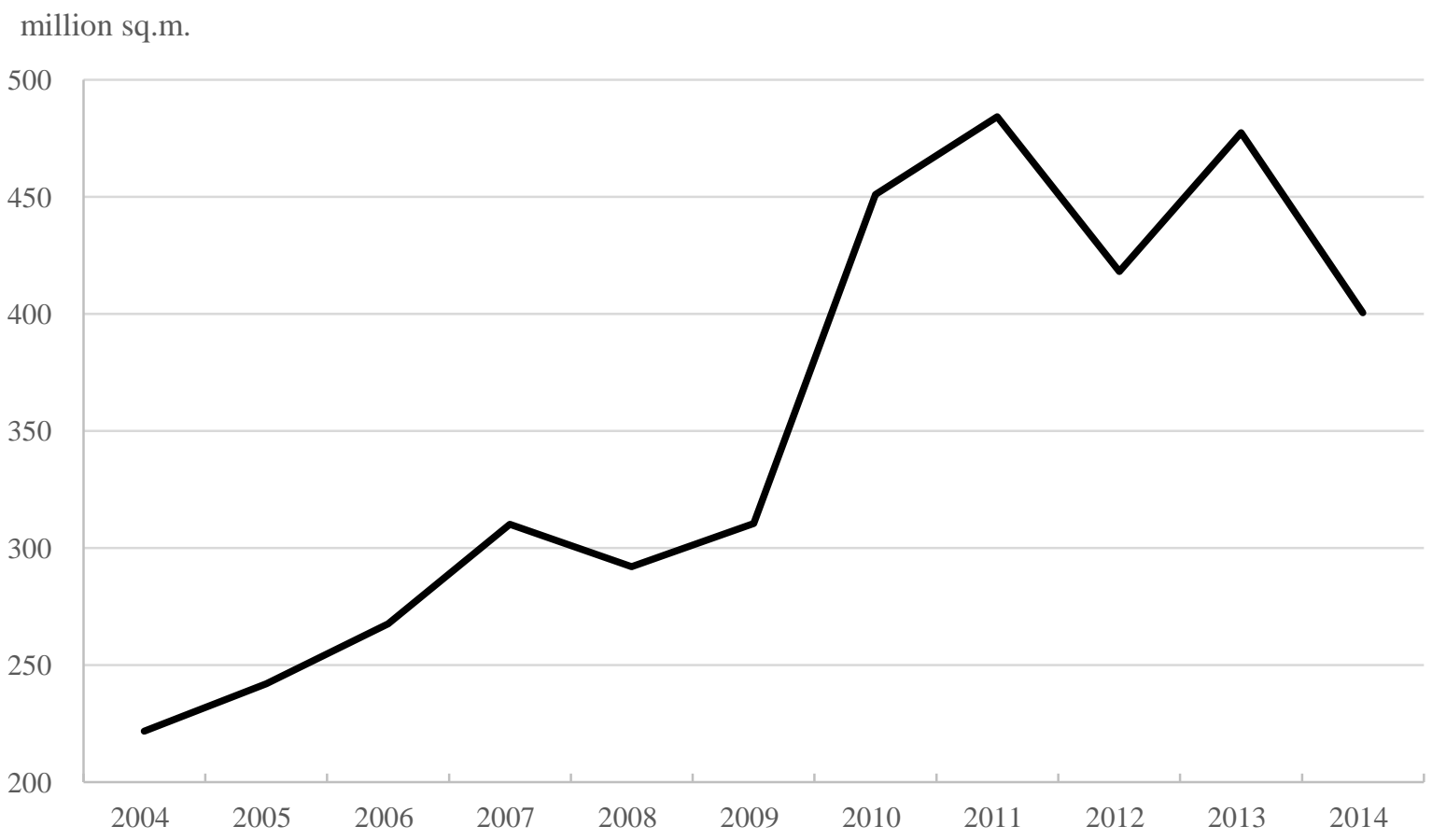


Figure 11: Housing Vacancy Rate Based on Urban Household Survey between 2002 and 2009

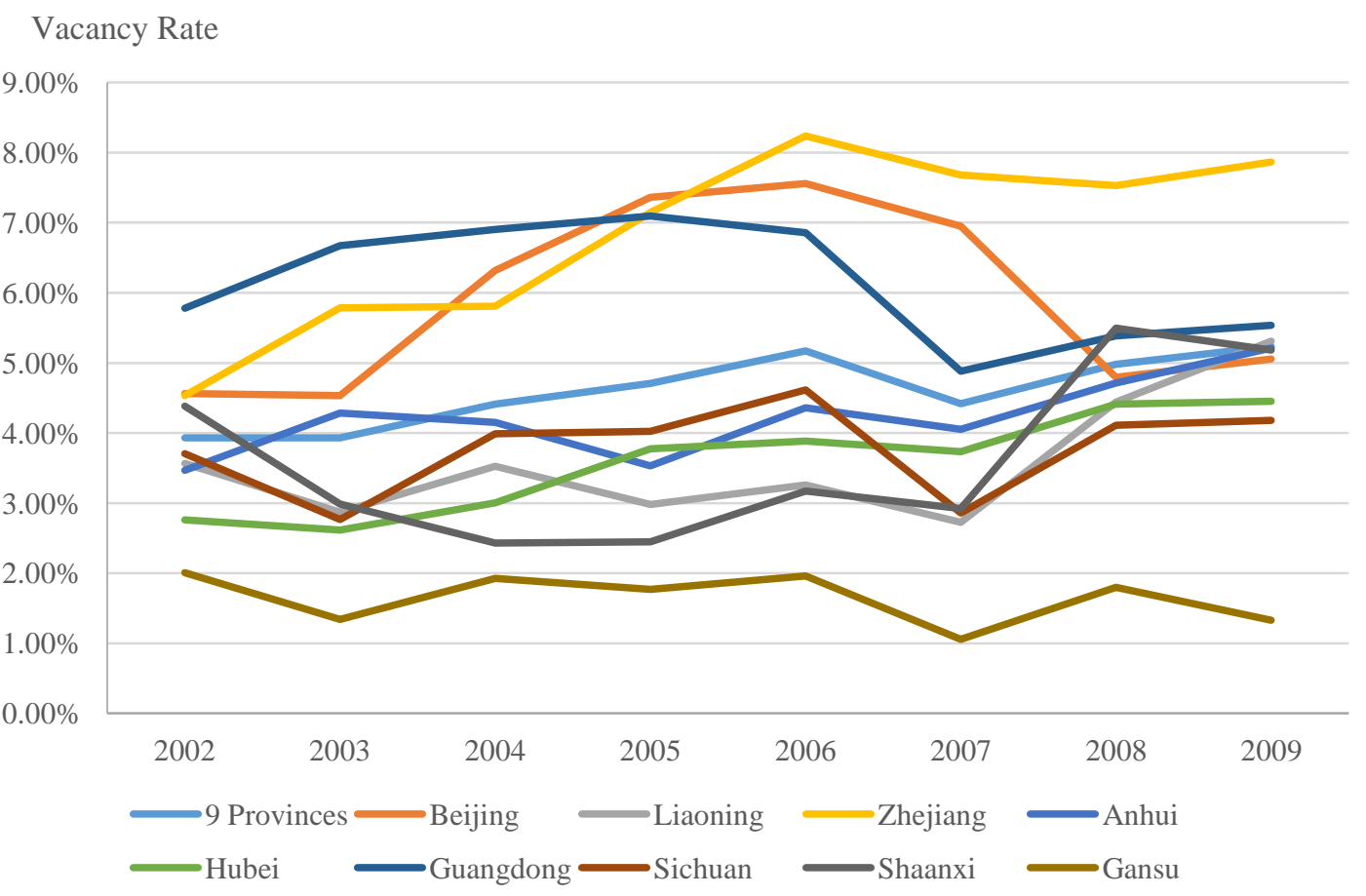


Figure 12: Quarterly Price-to-Rent Ratios in 12 Major Markets
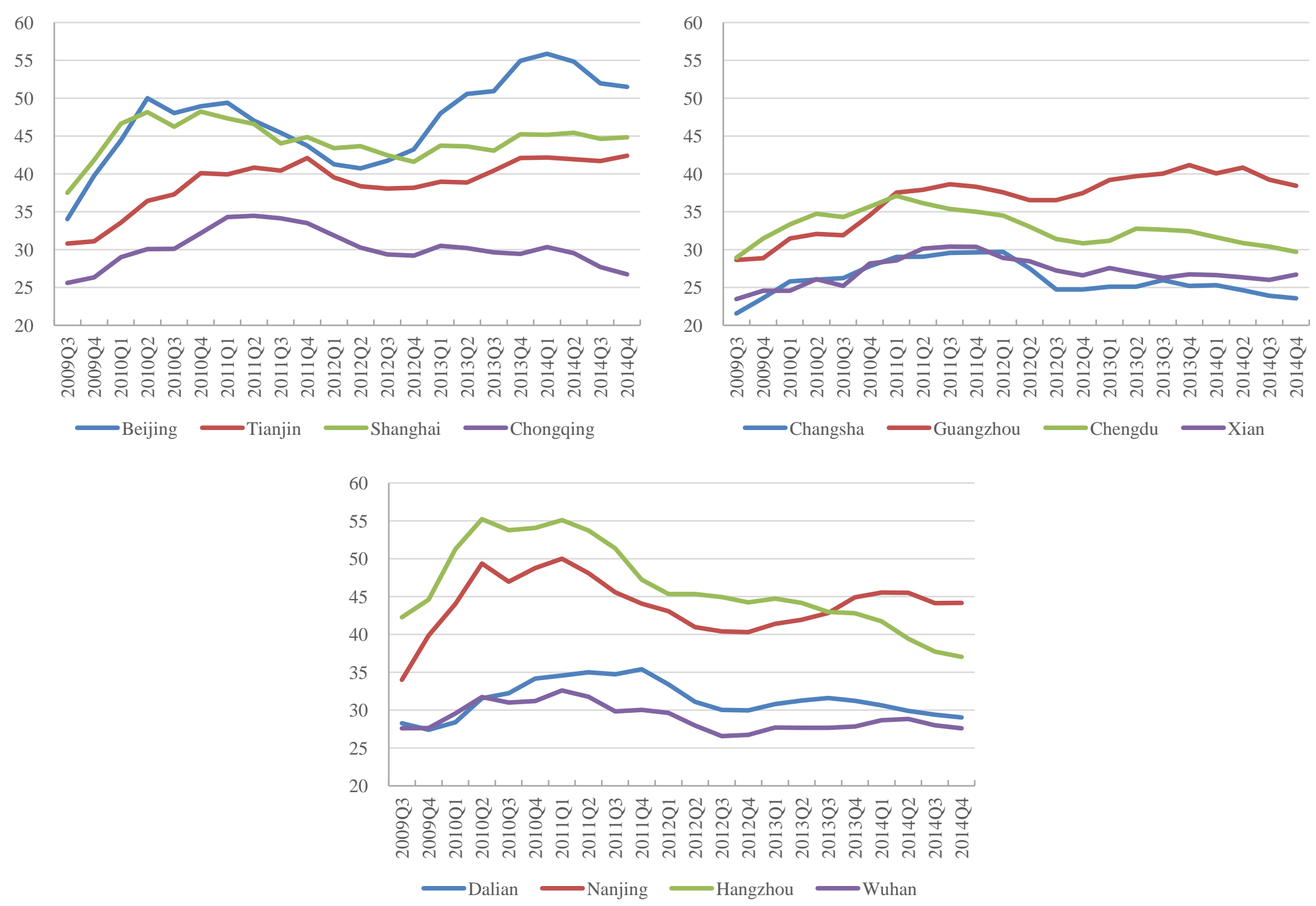
Figure 13: Annual Price-to-Income Ratios in 12 Major Markets
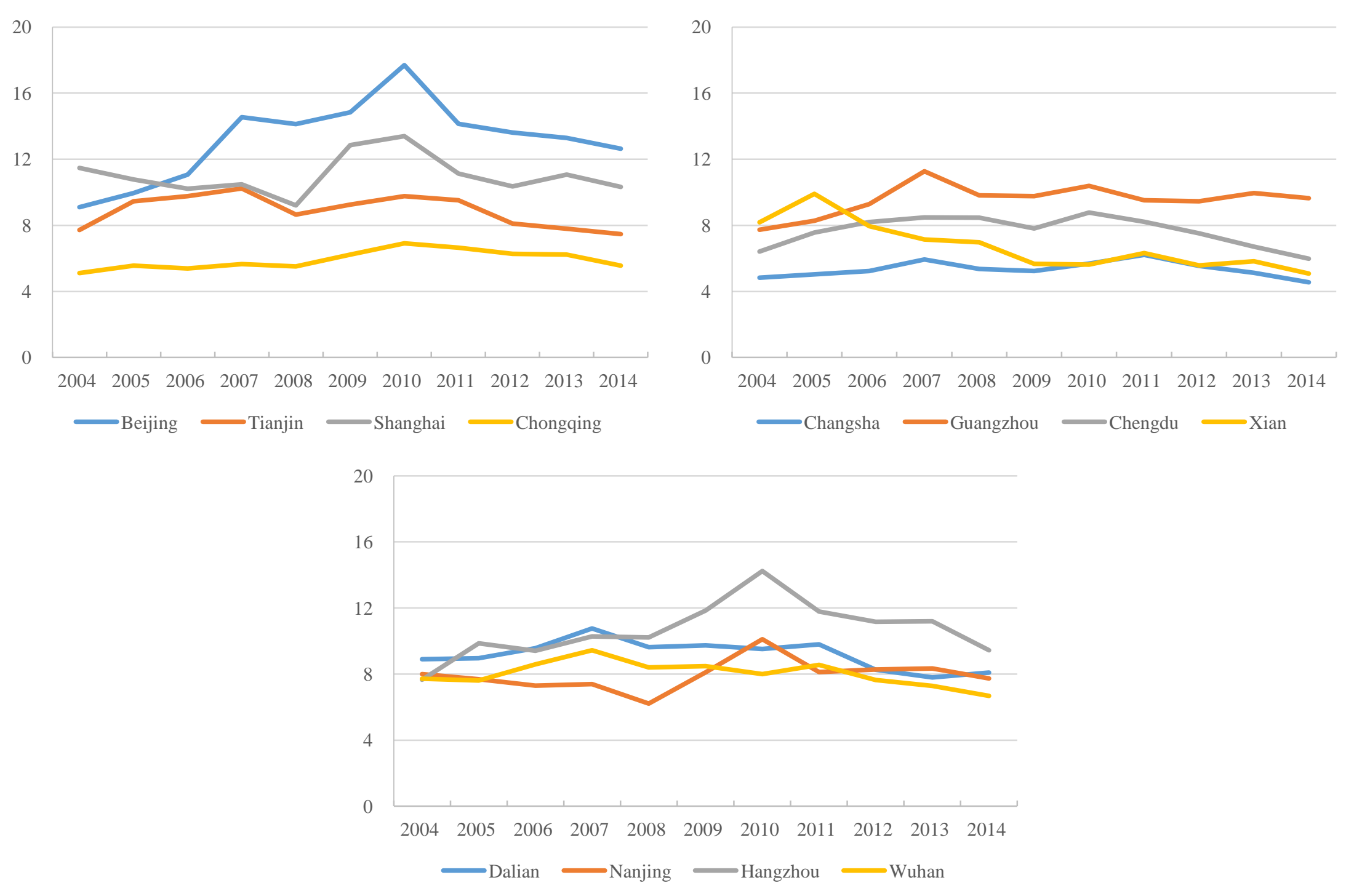
Table 1: Real House Price Appreciation Based on "Average Selling Price of Newly-Built Homes", 35 Major Cities, 2004-2014

\begin{tabular}{|c|c|c|}
\hline & Aggregate Real Price Growth (\%) & $\begin{array}{l}\text { Implied Per Annum Compound } \\
\text { Growth Rate (\%) }\end{array}$ \\
\hline Beijing & 226.4 & 11.6 \\
\hline Tianjin & 141.4 & 8.5 \\
\hline Shijiazhuang & 146.2 & 8.7 \\
\hline Taiyuan & 86.6 & 6.0 \\
\hline Hohhot & 206.5 & 11.0 \\
\hline Shenyang & 64.4 & 4.7 \\
\hline Dalian & 115.8 & 7.4 \\
\hline Changchun & 84.3 & 5.8 \\
\hline Harbin & 91.0 & 6.2 \\
\hline Shanghai & 158.8 & 9.2 \\
\hline Nanjing & 149.2 & 8.9 \\
\hline Hangzhou & 196.6 & 10.6 \\
\hline Ningbo & 162.2 & 9.4 \\
\hline Hefei & 215.9 & 11.3 \\
\hline Fuzhou & 218.6 & 11.4 \\
\hline Xiamen & 322.3 & 14.3 \\
\hline Nanchang & 147.6 & 8.8 \\
\hline Jinan & 95.8 & 6.4 \\
\hline Qingdao & 185.3 & 10.2 \\
\hline Zhengzhou & 131.1 & 8.1 \\
\hline Wuhan & 157.6 & 9.2 \\
\hline Changsha & 92.5 & 6.3 \\
\hline Guangzhou & 164.2 & 9.5 \\
\hline Shenzhen & 207.1 & 11.0 \\
\hline Nanning & 87.4 & 6.0 \\
\hline Haikou & 79.0 & 5.6 \\
\hline Chongqing & 156.9 & 9.2 \\
\hline Chengdu & 143.8 & 8.6 \\
\hline Guiyang & 121.7 & 7.7 \\
\hline Kunming & 147.4 & 8.8 \\
\hline Xian & 106.0 & 7.0 \\
\hline Lanzhou & 109.6 & 7.1 \\
\hline Xining & 55.4 & 4.2 \\
\hline Yinchuan & 51.6 & 3.9 \\
\hline Urumqi & 153.7 & 9.0 \\
\hline Aggregated & 96.4 & 6.5 \\
\hline
\end{tabular}


Table 2: Sample Volume of the Land Transaction Dataset

\begin{tabular}{ccc}
\hline & $\begin{array}{c}\text { Number of } \\
\text { Cities Covered }\end{array}$ & $\begin{array}{c}\text { Number of Land } \\
\text { Parcels Sold }\end{array}$ \\
\hline 2004 & 22 & 675 \\
2005 & 24 & 770 \\
2006 & 33 & 1,123 \\
2007 & 34 & 1,409 \\
2008 & 35 & 964 \\
2009 & 35 & 1,567 \\
2010 & 35 & 1,752 \\
2011 & 35 & 1,675 \\
2012 & 35 & 1,860 \\
2013 & 35 & 1,871 \\
2014 & 35 & 1,186 \\
\hline Aggregated & - & 14,852 \\
\hline
\end{tabular}




\begin{tabular}{|l|c|}
\hline \multicolumn{2}{|c|}{$\begin{array}{c}\text { Table 3: Chinese Residential Land Price Index Growth } \\
\text { 35 City Aggregate, 2004(1)-2014(4) } \\
\text { 44 quarters }\end{array}$} \\
\hline Total Appreciation & $357 \%$ \\
\hline Compound Quarterly Growth Rate & $3.6 \%$ \\
\hline Annualized Compound Quarterly Rate & $15.2 \%$ \\
\hline
\end{tabular}

\begin{tabular}{|c|c|c|c|}
\hline \multicolumn{4}{|c|}{$\begin{array}{l}\text { Table 4: Chinese Residential Land Price Index Growth } \\
\text { Regional Level, 2004h1-2014h2 } \\
22 \text { half years }\end{array}$} \\
\hline & East Region & Middle Region & West Region \\
\hline Total Appreciation & $324 \%$ & $326 \%$ & $231 \%$ \\
\hline $\begin{array}{l}\text { Compound Semi-Annual } \\
\text { Growth Rate }\end{array}$ & $7.1 \%$ & $7.1 \%$ & $5.9 \%$ \\
\hline $\begin{array}{l}\text { Annualized Compound } \\
\text { Semi-Annual Rate }\end{array}$ & $14.8 \%$ & $14.8 \%$ & $12.1 \%$ \\
\hline
\end{tabular}

\begin{tabular}{|c|c|c|c|c|c|}
\hline \multicolumn{6}{|c|}{$\begin{array}{l}\text { Table 5: Land Vs. House Price Growth } \\
12 \text { Major Markets, 2004-2014 }\end{array}$} \\
\hline \multirow[b]{2}{*}{ City } & \multicolumn{2}{|c|}{$\begin{array}{l}\text { Chinese Residential Land } \\
\text { Price Index Series }\end{array}$} & \multicolumn{2}{|c|}{$\begin{array}{l}\text { Average Price of Newly- } \\
\text { Built Homes Series }\end{array}$} & \multirow{2}{*}{$\begin{array}{c}\text { Ratio of } \\
\begin{array}{c}\text { Aggregate Land to } \\
\text { House Price } \\
\text { Growth }\end{array} \\
\text { Aggregate }\end{array}$} \\
\hline & $\begin{array}{l}\text { Aggregate } \\
\text { Growth }\end{array}$ & $\begin{array}{l}\text { Per Annum } \\
\text { Rate }\end{array}$ & $\begin{array}{l}\text { Aggregate } \\
\text { Growth }\end{array}$ & $\begin{array}{l}\text { Per Annum } \\
\text { Rate }\end{array}$ & \\
\hline Beijing & $1036 \%$ & $27.5 \%$ & $226 \%$ & $11.6 \%$ & 4.6 \\
\hline Changsha & $248 \%$ & $13.3 \%$ & $93 \%$ & $6.3 \%$ & 2.7 \\
\hline Chengdu & $201 \%$ & $11.6 \%$ & $144 \%$ & $8.6 \%$ & 1.4 \\
\hline Chongqing & $449 \%$ & $18.6 \%$ & $157 \%$ & $9.2 \%$ & 2.9 \\
\hline Dalian & $101 \%$ & $7.2 \%$ & $116 \%$ & $7.4 \%$ & 0.9 \\
\hline Guangzhou ${ }^{\top}$ & $169 \%$ & $15.2 \%$ & $75 \%$ & $7.5 \%$ & 2.3 \\
\hline Hangzhou & $273 \%$ & $14.1 \%$ & $197 \%$ & $10.6 \%$ & 1.4 \\
\hline Nanjing & $348 \%$ & $13.3 \%$ & $149 \%$ & $8.9 \%$ & 2.3 \\
\hline Shanghai $^{2}$ & $342 \%$ & $20.4 \%$ & $101 \%$ & $8.3 \%$ & 3.4 \\
\hline Tianjin & $332 \%$ & $15.7 \%$ & $141 \%$ & $8.5 \%$ & 2.4 \\
\hline Wuhan & $102 \%$ & $7.3 \%$ & $158 \%$ & $9.2 \%$ & 0.6 \\
\hline $\operatorname{Xian}^{1}$ & $78 \%$ & $8.6 \%$ & $50 \%$ & $5.4 \%$ & 1.6 \\
\hline
\end{tabular}

Notes:

1. Annual land price data for Guangzhou and Xian are available only from 2007-2014, or for eight years. Comparable house price data are used for the same period.

2. Annual land price data for Shanghai are available only from 2006-2014, or for night years. Comparable house price data are used for the same period. 
Table 6: Real House Price Appreciation, Constant-Quality Index, 2006-2014

\begin{tabular}{|c|c|c|}
\hline & Aggregate Real Price Growth & Implied Per Annum Compound Growth Rate \\
\hline Beijing & $384.5 \%$ & $19.8 \%$ \\
\hline Tianjin & $80.2 \%$ & $7.0 \%$ \\
\hline Shijiazhuang & $149.3 \%$ & $11.0 \%$ \\
\hline Taiyuan & $30.1 \%$ & $3.1 \%$ \\
\hline Hohhot & $125.5 \%$ & $9.7 \%$ \\
\hline Shenyang & $74.0 \%$ & $6.5 \%$ \\
\hline Dalian & $47.7 \%$ & $4.6 \%$ \\
\hline Changchun & $108.3 \%$ & $8.7 \%$ \\
\hline Harbin & $66.4 \%$ & $6.0 \%$ \\
\hline Shanghai & $165.2 \%$ & $11.8 \%$ \\
\hline Nanjing & $145.3 \%$ & $10.8 \%$ \\
\hline Hangzhou & $72.1 \%$ & $6.4 \%$ \\
\hline Ningbo & $55.1 \%$ & $5.1 \%$ \\
\hline Hefei & $59.7 \%$ & $5.5 \%$ \\
\hline Fuzhou & $201.9 \%$ & $13.5 \%$ \\
\hline Xiamen & $320.6 \%$ & $17.8 \%$ \\
\hline Nanchang & $56.7 \%$ & $5.3 \%$ \\
\hline Jinan & $27.4 \%$ & $2.8 \%$ \\
\hline Qingdao & $105.6 \%$ & $8.6 \%$ \\
\hline Zhengzhou & $126.3 \%$ & $9.8 \%$ \\
\hline Wuhan & $55.7 \%$ & $5.2 \%$ \\
\hline Changsha & $105.7 \%$ & $8.6 \%$ \\
\hline Guangzhou & $172.3 \%$ & $12.1 \%$ \\
\hline Shenzhen & $110.4 \%$ & $8.9 \%$ \\
\hline Nanning & $45.5 \%$ & $4.4 \%$ \\
\hline Haikou & $125.4 \%$ & $9.7 \%$ \\
\hline Chongqing & $104.8 \%$ & $8.5 \%$ \\
\hline Chengdu & $56.0 \%$ & $5.2 \%$ \\
\hline Guiyang & $71.7 \%$ & $6.4 \%$ \\
\hline Kunming & $131.4 \%$ & $10.1 \%$ \\
\hline Xian & $61.2 \%$ & $5.6 \%$ \\
\hline Lanzhou & $114.6 \%$ & $9.1 \%$ \\
\hline Xining & $92.6 \%$ & $7.8 \%$ \\
\hline Yinchuan & $54.5 \%$ & $5.1 \%$ \\
\hline Urumqi & $157.1 \%$ & $11.4 \%$ \\
\hline Aggregated & $138.5 \%$ & $10.4 \%$ \\
\hline
\end{tabular}


Table 7: Inventory Level of 119 Listed Housing Developers in China, 2006-2013

\begin{tabular}{cccc}
\hline & Average Turnover Ratio & $\begin{array}{c}\text { Aggregated Inventory } \\
\text { (in billion yuan) }\end{array}$ & $\begin{array}{c}\text { Average Normalized } \\
\text { Inventory }\end{array}$ \\
\hline 2004 & $44.30 \%$ & 76.00 & $23.70 \%$ \\
2005 & $40.54 \%$ & 87.63 & $24.69 \%$ \\
2006 & $42.71 \%$ & 136.45 & $28.32 \%$ \\
2007 & $45.20 \%$ & 226.93 & $30.54 \%$ \\
2008 & $33.08 \%$ & 356.92 & $44.65 \%$ \\
2009 & $30.01 \%$ & 377.54 & $37.83 \%$ \\
2010 & $28.97 \%$ & 517.44 & $41.92 \%$ \\
2011 & $24.90 \%$ & 707.81 & $45.74 \%$ \\
2012 & $24.22 \%$ & 815.20 & $44.41 \%$ \\
2013 & $25.26 \%$ & 1039.71 & $44.80 \%$ \\
\hline
\end{tabular}

Source: authors' calculations based on firms' annual financial reports. 
Table 8: Supply vs. Demand over Time, National Level and 35 Major Cities

\begin{tabular}{|c|c|c|c|c|c|c|c|c|c|}
\hline & \multicolumn{3}{|c|}{$\begin{array}{c}\text { Annual Average Supply } \\
\text { (thousand units) }\end{array}$} & \multicolumn{3}{|c|}{$\begin{array}{c}\text { Annual Average Demand } \\
\text { (thousand units) }\end{array}$} & \multicolumn{3}{|c|}{ Supply-Demand Ratio } \\
\hline & $\begin{array}{l}2001- \\
2010 \\
\end{array}$ & $\begin{array}{l}2011- \\
2012 \\
\end{array}$ & $\begin{array}{l}2001- \\
2012 \\
\end{array}$ & $\begin{array}{l}2001- \\
2010 \\
\end{array}$ & $\begin{array}{l}2011- \\
2012 \\
\end{array}$ & $\begin{array}{l}2001- \\
2012 \\
\end{array}$ & $\begin{array}{l}2001- \\
2010 \\
\end{array}$ & $\begin{array}{l}2011- \\
2012 \\
\end{array}$ & $\begin{array}{l}2001- \\
2012 \\
\end{array}$ \\
\hline Nation & 6739.32 & 10559.67 & 7376.04 & 7768.63 & 9680.24 & 8087.23 & $86.75 \%$ & $109.08 \%$ & $91.21 \%$ \\
\hline Beijing & 243.28 & 146.88 & 227.21 & 281.44 & 311.11 & 286.39 & $86.44 \%$ & $47.21 \%$ & $79.34 \%$ \\
\hline Tianjin & 114.45 & 173.62 & 124.32 & 92.72 & 159.00 & 103.77 & $123.44 \%$ & $109.19 \%$ & $119.80 \%$ \\
\hline Shijiazhuang & 41.03 & 80.99 & 47.69 & 39.39 & 55.72 & 42.11 & $104.16 \%$ & $145.36 \%$ & $113.25 \%$ \\
\hline Taiyuan & 37.79 & 34.90 & 37.31 & 28.07 & 45.75 & 31.02 & $134.64 \%$ & $76.29 \%$ & $120.30 \%$ \\
\hline Hohhot & 41.04 & 29.50 & 39.12 & 22.64 & 24.47 & 22.94 & $181.30 \%$ & $120.53 \%$ & $170.50 \%$ \\
\hline Shenyang & 99.42 & 192.02 & 114.85 & 79.84 & 86.27 & 80.92 & $124.52 \%$ & $222.57 \%$ & $141.94 \%$ \\
\hline Dalian & 56.46 & 89.12 & 61.91 & 60.04 & 72.43 & 62.11 & $94.04 \%$ & $123.04 \%$ & $99.67 \%$ \\
\hline Changchun & 46.35 & 83.38 & 52.52 & 58.43 & 61.41 & 58.93 & $79.33 \%$ & $135.79 \%$ & $89.13 \%$ \\
\hline Harbin & 105.93 & 111.88 & 106.92 & 83.52 & 46.81 & 77.40 & $126.84 \%$ & $239.01 \%$ & $138.15 \%$ \\
\hline Shanghai & 258.93 & 151.51 & 241.02 & 304.68 & 489.51 & 335.48 & $84.98 \%$ & $30.95 \%$ & $71.84 \%$ \\
\hline Nanjing & 58.59 & 113.51 & 67.75 & 49.50 & 105.14 & 58.77 & $118.37 \%$ & $107.97 \%$ & $115.27 \%$ \\
\hline Hangzhou & 72.83 & 80.12 & 74.05 & 96.57 & 152.43 & 105.88 & $75.42 \%$ & $52.56 \%$ & $69.93 \%$ \\
\hline Ningbo & 63.78 & 54.59 & 62.25 & 72.22 & 117.12 & 79.70 & $88.32 \%$ & $46.61 \%$ & $78.10 \%$ \\
\hline Hefei & 46.24 & 68.74 & 49.99 & 45.14 & 53.63 & 46.55 & $102.45 \%$ & $128.17 \%$ & $107.39 \%$ \\
\hline Fuzhou & 51.62 & 48.95 & 51.17 & 43.30 & 62.25 & 46.46 & $119.22 \%$ & $78.63 \%$ & $110.16 \%$ \\
\hline Xiamen & 54.60 & 26.43 & 49.90 & 53.28 & 56.24 & 53.77 & $102.48 \%$ & $46.98 \%$ & $92.81 \%$ \\
\hline Nanchang & 30.50 & 141.41 & 48.98 & 26.63 & 49.39 & 30.42 & $114.52 \%$ & $286.30 \%$ & $161.01 \%$ \\
\hline Jinan & 35.43 & 38.76 & 35.99 & 40.67 & 52.37 & 42.62 & $87.14 \%$ & $74.01 \%$ & $84.45 \%$ \\
\hline Qingdao & 66.88 & 85.35 & 69.96 & 45.95 & 66.64 & 49.40 & $145.54 \%$ & $128.07 \%$ & $141.61 \%$ \\
\hline Zhengzhou & 52.66 & 193.33 & 76.11 & 37.62 & 57.41 & 40.91 & $140.00 \%$ & $336.77 \%$ & $186.01 \%$ \\
\hline Wuhan & 68.82 & 90.27 & 72.40 & 46.32 & 79.72 & 51.89 & $148.57 \%$ & $113.24 \%$ & $139.52 \%$ \\
\hline Changsha & 50.93 & 116.92 & 61.93 & 50.34 & 60.96 & 52.11 & $101.16 \%$ & $191.79 \%$ & $118.83 \%$ \\
\hline Guangzhou & 138.91 & 82.90 & 129.57 & 148.19 & 214.17 & 159.19 & $93.74 \%$ & $38.71 \%$ & $81.40 \%$ \\
\hline Shenzhen & 181.08 & 31.43 & 156.14 & 235.25 & 201.04 & 229.55 & $76.97 \%$ & $15.63 \%$ & $68.02 \%$ \\
\hline Nanning & 37.50 & 59.56 & 41.18 & 36.13 & 39.43 & 36.68 & $103.81 \%$ & $151.07 \%$ & $112.28 \%$ \\
\hline Haikou & 11.25 & 15.28 & 11.92 & 14.54 & 17.41 & 15.02 & $77.37 \%$ & $87.76 \%$ & $79.38 \%$ \\
\hline Chongqing & 223.99 & 431.22 & 258.53 & 128.81 & 181.15 & 137.54 & $173.88 \%$ & $238.05 \%$ & $187.97 \%$ \\
\hline Chengdu & 100.11 & 94.14 & 99.12 & 51.70 & 78.38 & 56.15 & $193.63 \%$ & $120.11 \%$ & $176.52 \%$ \\
\hline Guiyang & 37.54 & 51.98 & 39.95 & 26.35 & 38.09 & 28.31 & $142.45 \%$ & $136.46 \%$ & $141.10 \%$ \\
\hline Kunming & 51.42 & 64.82 & 53.65 & 40.22 & 53.20 & 42.39 & $127.83 \%$ & $121.83 \%$ & $126.57 \%$ \\
\hline Xian & 59.23 & 93.80 & 64.99 & 58.10 & 67.09 & 59.60 & $101.95 \%$ & $139.82 \%$ & $109.05 \%$ \\
\hline Lanzhou & 36.00 & 31.80 & 35.30 & 21.63 & 39.86 & 24.67 & $166.43 \%$ & $79.79 \%$ & $143.10 \%$ \\
\hline Xining & 16.06 & 48.85 & 21.52 & 19.89 & 37.27 & 22.79 & $80.74 \%$ & $131.05 \%$ & $94.45 \%$ \\
\hline Yinchuan & 36.50 & 49.15 & 38.61 & 21.06 & 27.59 & 22.15 & $173.29 \%$ & $178.11 \%$ & $174.29 \%$ \\
\hline Urumqi & 46.25 & 50.36 & 46.93 & 57.69 & 68.08 & 59.42 & $80.16 \%$ & $73.97 \%$ & $78.98 \%$ \\
\hline
\end{tabular}

Note: See Appendix 1 for the details of how supply and demand were estimated. 
Table 9: Expected Capital Gain Based on the User Cost Model

\begin{tabular}{|c|c|c|}
\hline & $\begin{array}{c}\text { Expected Capital Gain Equalizing } \\
\text { User Cost and Rent }\end{array}$ & $\begin{array}{c}\text { Per Annum Compound Growth Rate } \\
\text { between } 2006 \text { and } 2014\end{array}$ \\
\hline Beijing & $7.3 \%$ & $19.8 \%$ \\
\hline Tianjin & $6.9 \%$ & $7.0 \%$ \\
\hline Shijiazhuang & $6.5 \%$ & $11.0 \%$ \\
\hline Taiyuan & $5.8 \%$ & $3.1 \%$ \\
\hline Hohhot & $5.2 \%$ & $9.7 \%$ \\
\hline Shenyang & $5.7 \%$ & $6.5 \%$ \\
\hline Dalian & $5.8 \%$ & $4.6 \%$ \\
\hline Changchun & $5.1 \%$ & $8.7 \%$ \\
\hline Harbin & $4.6 \%$ & $6.0 \%$ \\
\hline Shanghai & $7.0 \%$ & $11.8 \%$ \\
\hline Nanjing & $7.0 \%$ & $10.8 \%$ \\
\hline Hangzhou & $6.5 \%$ & $6.4 \%$ \\
\hline Ningbo & $6.3 \%$ & $5.1 \%$ \\
\hline Hefei & $6.0 \%$ & $5.5 \%$ \\
\hline Fuzhou & $6.3 \%$ & $13.5 \%$ \\
\hline Xiamen & $7.2 \%$ & $17.8 \%$ \\
\hline Nanchang & $6.6 \%$ & $5.3 \%$ \\
\hline Jinan & $6.2 \%$ & $2.8 \%$ \\
\hline Qingdao & $6.9 \%$ & $8.6 \%$ \\
\hline Zhengzhou & $5.7 \%$ & $9.8 \%$ \\
\hline Wuhan & $5.6 \%$ & $5.2 \%$ \\
\hline Changsha & $5.0 \%$ & $8.6 \%$ \\
\hline Guangzhou & $6.6 \%$ & $12.1 \%$ \\
\hline Shenzhen & $6.9 \%$ & $8.9 \%$ \\
\hline Haikou & $5.3 \%$ & $4.4 \%$ \\
\hline Nanning & $4.8 \%$ & $9.7 \%$ \\
\hline Chongqing & $5.5 \%$ & $8.5 \%$ \\
\hline Chengdu & $5.9 \%$ & $5.2 \%$ \\
\hline Guiyang & $4.7 \%$ & $6.4 \%$ \\
\hline Kunming & $5.7 \%$ & $10.1 \%$ \\
\hline Xi'an & $5.5 \%$ & $5.6 \%$ \\
\hline Lanzhou & $5.4 \%$ & $9.1 \%$ \\
\hline Xining & $4.5 \%$ & $7.8 \%$ \\
\hline Yinchuan & $5.5 \%$ & $5.1 \%$ \\
\hline Urumqi & $5.6 \%$ & $11.4 \%$ \\
\hline
\end{tabular}


Table 10: Can Year and City Fixed Effects Explain Local Housing Price Growth?

(Dependent Variable: Log Change in Real Annual Housing Price Index)

\begin{tabular}{|c|c|c|c|}
\hline Independent Variables & $(1)$ & $(2)$ & $(3)$ \\
\hline Year Fixed Effect & Yes & No & Yes \\
\hline City Fixed Effect & No & Yes & Yes \\
\hline $\mathrm{R}^{2}$ & 0.39 & 0.12 & 0.50 \\
\hline Adjusted $\mathrm{R}^{2}$ & 0.37 & -0.03 & 0.41 \\
\hline F Stat. for the Joint Test of All Year Fixed Effects Equaling 0 & $25.08 * * *$ & - & $26.38 * * *$ \\
\hline F Stat. for the Joint Test of All City Fixed Effects Equaling 0 & - & 0.82 & $1.34 *$ \\
\hline Number of Observations & 244 & 244 & 244 \\
\hline
\end{tabular}


Table 11: Can Fundamental Factors Explain Local Housing Price Growth?

(Dependent Variable: Log Change in Real Annual Housing Price Index)

\begin{tabular}{|c|c|c|c|}
\hline Independent Variables & $(1)$ & $(2)$ & $(3)$ \\
\hline Housing Inventory at the Beginning of this Year & -0.0529 & -0.0443 & -0.0421 \\
\hline / Housing Sales in the Previous Year & $(0.0101) * * *$ & $(0.0096) * * *$ & $(0.0099)^{* * *}$ \\
\hline Housing Receiving Presale Permits in this Year & -0.0356 & -0.0008 & -0.0050 \\
\hline / Housing Sales in this Year & $(0.0140)^{* *}$ & $(0.0150)$ & $(0.0150)$ \\
\hline \multirow[t]{2}{*}{ Lagged Housing Price Level } & - & -0.3981 & -0.4040 \\
\hline & - & $(0.0588) * * *$ & $(0.0584)^{* * *}$ \\
\hline \multirow[t]{2}{*}{ Lagged Housing Price Change } & - & 0.0428 & 0.0138 \\
\hline & - & $(0.0650)$ & $(0.0650)$ \\
\hline \multirow[t]{2}{*}{ Expected Employment Growth } & - & - & -0.0047 \\
\hline & - & - & $(0.0034)$ \\
\hline \multirow[t]{2}{*}{ Expected Export Growth } & - & - & 0.0020 \\
\hline & - & - & $(0.0008) * *$ \\
\hline \multirow[t]{2}{*}{ Residential Land Supply Volume } & - & - & -0.0030 \\
\hline & - & - & $(0.0093)$ \\
\hline \multirow[t]{2}{*}{ Construction Cost Change } & - & - & 0.2313 \\
\hline & - & - & $(0.3057)$ \\
\hline \multirow[t]{2}{*}{ Expected Outstanding Loan Balance Growth } & - & - & 0.0017 \\
\hline & - & - & $(0.0012)$ \\
\hline Year Fixed Effect & Yes & Yes & Yes \\
\hline City Fixed Effect & Yes & Yes & Yes \\
\hline $\mathrm{R}^{2}$ & 0.56 & 0.70 & 0.72 \\
\hline Number of Observations & 244 & 209 & 209 \\
\hline
\end{tabular}

Note:* $p<0.1, * * p<0.05, * * * p<0.01$ 